\title{
Metabolic syndrome in adults: relation with diet and other lifestyle factors
}

Ishu Kataria ${ }^{1}$, Ravinder Chadha ${ }^{1}$, Renuka Pathak ${ }^{1}$

1 Department of Food and Nutrition, Lady Irwin College, University of Delhi, India

\section{Abstract}

Metabolic syndrome is a constellation of risk factors that has the potential of developing into cardiovascular disease or increase the susceptibility to it. It is present worldwide with now even developing countries getting overwhelmed by its burden. With a shift towards unhealthy diet coupled with sedentary lifestyle, development of metabolic syndrome is on the rise even among young adults. One of the main causes of this problem is faulty diet, so any means to reduce the incidence of the syndrome involves the modification of the existing diets rich in saturated fat, sodium and cholesterol. This review focusses on efficacy of different dietary patterns for combating the syndrome along with other lifestyle risk factors. It also highlights newer advancements in the field of Metabolic Syndrome, which can serve as potential strategies to combat it. Public health interventions targeting adults, therefore, should center on prevention through education, modification of diet and lifestyle, and focusing on environment, so that these changes are acceptable and sustainable.

\section{Keywords}

Metabolic Syndrome; Diet; Lifestyle 


\section{Introduction}

Metabolic syndrome (MetS) is a complicated disorder that increases a person's risk to cardiovascular diseases (CVD) and diabetes (DM). It is a cluster of interrelated factors characterized by high fasting blood glucose, increased level of triglycerides, low levels of high density cholesterol (HDL), elevated blood pressure and abdominal obesity [1]. However, defining MetS is a complicated task as there is no one universal definition. With its increasing prevalence in childhood and adulthood, it poses immense future implications on the global burden of disease relating to obesity and sedentary lifestyle. MetS thus can be viewed from both a public health as well as a clinical perspective. While in the public health arena it focuses on modification of lifestyle, at clinical level, it confluences on diagnosis of risk factors related to MetS including lifestyle related factors. Despite there being a disagreement on the consensus of one universal definition, there appears to be an agreement that MetS poses risk for developing CVD and DM $[2,3]$. Though MetS is not an absolute risk factor, it presents a impressive risk of developing CVD in future [4,5]. The concept of 'Syndrome X' which was renamed as MetS later, was pioneered by Reaven [6], estimating it as an importante factor in the development of CVD and DM. He identified insulin resistance and subsequent hyperinsulinemia as the indispensable underlying risk factors for hypertension, hyperlipidemia, diabetes and eventually CVD. Although, he did not acknowledge obesity as caused by insulin resistance, he did acknowledge its correlation with Syndrome X or MetS. It was inferred then that weight maintenance and physical activity were the pivotal elements for the treatment [7]. The beginning of defining MetS began in 1998, by a consultation group on the definition of diabetes for the World Health Organization (WHO) [8]. This was followed by the European Group for the study of Insulin Resistance (EGIR) [9] in 1999, the National Cholesterol Education Program Adult Treatment Panel III (NCEP:ATPIII) [10] in 2001, the American Association of Clinical Endocrinology (AACE) [11] in 2003, the International Diabetes Federation (IDF) [12], and the American Heart Association/National Heart, Lung, and Blood Institute (AHA/NHLBI) [13] in 2005.The criteria for defining MetS vary among all these definitions (Table I).

Another pertinent aspect relating to the MetS is the applicability of the above defined criteria in relation to various ethnic groups. Ethnicity poses an important question for diagnosis of MetS. Due to mixed ethnicity in the world, it is important to be pragmatic with this aspect. A primary perspective lies in the fact that a common definition to diagnose MetS must be used worldwide, keeping into consideration the difference between sexes and ethnic groups. The different proposed definitions of MetS have varied applicability across various ethnicities. The dilemma arises in the case of defining obesity cut offs as type $2 \mathrm{DM}$ is at lower levels of obesity in Asians in contrast to Europeans. Solution to this dilemma has been recognized by IDF that has supported new ethnic cutoffs to diagnose MetS. However, it is imperative to possess one definition that is applicable worldwide, keeping in view the amplifying epidemic of CVD and type 2 DM [4]. Regardless of the varying criteria proposed by different definitions, the prevalence of MetS is on the rise in both western and Asian countries [14-16]. Increment in the proportion of diagnosed individuals can be related to increase in age and BMI [17]. Not only the western societies, but also the developing countries are now getting overwhelmed in the burden of this problem. This rise can be attributed to the transition in the lifestyle from a traditional to a western one. The genesis of MetS and obesity in developing countries relates to demographic transition (shift to low fertility, low mortality, and higher life expectancy), and epidemiological transition (from widely prevalent infectious diseases to a pattern of a high prevalence of lifestyle related diseases) congregating genetics and environment [5,18-20]. The double burden of under and over nutrition in the developing countries is leading to the increased risk for CVD and sequential morbidity and mortality. Health interventions focusing on favorable dietary and lifestyle practices are the need of the hour in developing countries simultaneous with the adequate support of government and legislative bodies. Therefore, this review was undertaken to assess the current dietary patterns and newer advancements effective in combating MetS. 


\begin{tabular}{|c|c|c|c|c|c|}
\hline \multirow{2}{*}{$\begin{array}{l}\text { Expert group/ } \\
\text { organization }\end{array}$} & \multicolumn{5}{|c|}{ Diagnostic criteria } \\
\hline & Glycemia & Obesity & Dyslipidemia & BP & Any other \\
\hline \multirow[t]{2}{*}{$\begin{array}{l}\text { World Health } \\
\text { Organization } \\
(\text { WHO), } 1998\end{array}$} & $>100 \mathrm{mg} / \mathrm{dl}$ & $\begin{array}{c}\text { WHR: } \\
\text { men>0.9, } \\
\text { women }>0.85 \\
\text { BMI> }>30 \mathrm{~kg} / \mathrm{m}^{2}\end{array}$ & $\begin{array}{c}\text { TG:150 mg/dl or greater } \\
\text { and/or } \\
\text { HDL-C: men }<40 \mathrm{mg} / \mathrm{dl}, \\
\text { women }<50 \mathrm{mg} / \mathrm{dl}\end{array}$ & $\begin{array}{c}140 / 90 \mathrm{mmHg} \\
\text { or greater }\end{array}$ & $\begin{array}{l}\text { Microalbuminuria } \\
20 \mu g / m i n \text { or } \\
\text { greater } \\
30 \mathrm{mg} / \mathrm{g} \text { or greater }\end{array}$ \\
\hline & \multicolumn{5}{|c|}{ Insulin resistance plus two of the above } \\
\hline \multirow[t]{2}{*}{$\begin{array}{l}\text { European Group for } \\
\text { the Study of Insulin } \\
\text { Resistance (EGIR), } \\
1999\end{array}$} & $\begin{array}{l}110 \mathrm{mg} / \mathrm{dl} \\
\text { or greater }\end{array}$ & $\begin{array}{l}\text { WC: men } 94 \mathrm{~cm} \text { or } \\
\text { greater, } \\
\text { women } 80 \mathrm{~cm} \text { or } \\
\text { greater }\end{array}$ & $\begin{array}{c}\text { TG: } 150 \mathrm{mg} / \mathrm{dl} \text { or greater } \\
\text { and/or } \\
\text { HDL-C: }<39 \mathrm{mg} / \mathrm{dl} \text { in } \\
\text { men or women }\end{array}$ & $\begin{array}{c}140 / 90 \mathrm{mmHg} \\
\text { or greater }\end{array}$ & \\
\hline & \multicolumn{5}{|c|}{ Insulin resistance plus two of the above } \\
\hline \multirow{2}{*}{$\begin{array}{l}\text { National Cholesterol } \\
\text { Education } \\
\text { Program Adult } \\
\text { Treatment Panel III } \\
\text { (NCEP:ATPIII) } 2001\end{array}$} & $\begin{array}{l}110 \mathrm{mg} / \mathrm{dl} \\
\text { or greater }\end{array}$ & $\begin{array}{l}\text { WC: } \text { men }>102 \mathrm{~cm}, \\
\quad \text { women }>88 \mathrm{~cm}\end{array}$ & $\begin{array}{l}\text { TG: } 150 \mathrm{mg} / \mathrm{dl} \text { or greater, } \\
\text { HDL-C: } \mathrm{men}<40 \mathrm{mg} / \mathrm{dl}, \\
\text { women }<50 \mathrm{mg} / \mathrm{dl}\end{array}$ & $\begin{array}{c}130 / 85 \mathrm{mmHg} \\
\text { or greater }\end{array}$ & \\
\hline & \multicolumn{5}{|c|}{ Any three or more of the above } \\
\hline \multirow{2}{*}{$\begin{array}{l}\text { American } \\
\text { Association } \\
\text { of Clinical } \\
\text { Endocrinology } \\
\text { (AACE), } 2003\end{array}$} & $\begin{array}{l}\text { Impaired } \\
\text { Glucose } \\
\text { Tolerance }\end{array}$ & $\begin{array}{c}\text { BMI: } 25 \mathrm{~kg} / \mathrm{m}^{2} \text { or } \\
\text { greater }\end{array}$ & $\begin{array}{l}\text { TG: } 150 \mathrm{mg} / \mathrm{dl} \text { or greater } \\
\text { and/or HDL-C: men<40 } \\
\mathrm{mg} / \mathrm{dl} \text {, women }<50 \mathrm{mg} / \mathrm{dl}\end{array}$ & $\begin{array}{c}130 / 85 \mathrm{mmHg} \\
\text { or greater }\end{array}$ & \\
\hline & \multicolumn{5}{|c|}{ IGT plus two or more of the above } \\
\hline \multirow{2}{*}{$\begin{array}{l}\text { American Heart } \\
\text { Association/National } \\
\text { Heart, Lung, and } \\
\text { Blood Institute } \\
\text { (AHA/NHLBI), } 2005\end{array}$} & $\begin{array}{l}100 \mathrm{mg} / \mathrm{dl} \\
\text { or greater }\end{array}$ & $\begin{array}{l}\text { WC: men } 102 \mathrm{~cm} \text { or } \\
\text { greater, } \\
\text { women } 88 \mathrm{~cm} \text { or } \\
\text { greater }\end{array}$ & $\begin{array}{c}\text { TG: } 150 \mathrm{mg} / \mathrm{dl} \text { or greater; } \\
\text { HDL-C: men< } 0 \mathrm{mg} / \mathrm{dl} \\
\text { women<50 mg/dl }\end{array}$ & $\begin{array}{c}130 / 85 \mathrm{mmHg} \\
\text { or greater }\end{array}$ & \\
\hline & \multicolumn{5}{|c|}{ Any three of the above } \\
\hline \multirow[t]{2}{*}{$\begin{array}{l}\text { International } \\
\text { Diabetes Federation } \\
\text { (IDF), } 2005\end{array}$} & $\begin{array}{l}100 \mathrm{mg} / \mathrm{dl} \\
\text { or greater }\end{array}$ & $\mathrm{BMI}>30 \mathrm{~kg} / \mathrm{m}^{2}$ & $\begin{array}{l}\text { TG: } 150 \mathrm{mg} / \mathrm{dl} \text { or greater; } \\
\text { HDL-C: } \mathrm{men}<40 \mathrm{mg} / \mathrm{dl} \\
\text { women }<50 \mathrm{mg} / \mathrm{dl}\end{array}$ & $\begin{array}{c}130 / 85 \mathrm{mmHg} \\
\text { or greater }\end{array}$ & \\
\hline & \multicolumn{5}{|c|}{ Central obesity plus two of the above } \\
\hline \multirow[t]{2}{*}{$\begin{array}{l}\text { Consensus definition } \\
\text { (incorporating IDF } \\
\text { and AHA/NHLBI } \\
\text { definitions), } 2005\end{array}$} & $\begin{array}{l}100 \mathrm{mg} / \mathrm{dl} \\
\text { or greater }\end{array}$ & $\begin{array}{l}\text { Elevated WC } \\
\text { (according to } \\
\text { population and } \\
\text { country-specific } \\
\text { definitions)* }\end{array}$ & $\begin{array}{c}\text { TG: } 150 \mathrm{mg} / \mathrm{dl} \text { or greater; } \\
\text { HDL-C: } \mathrm{men}<40 \mathrm{mg} / \mathrm{dl} \\
\text { women<50 mg/dl }\end{array}$ & $\begin{array}{c}130 / 85 \mathrm{mmHg} \\
\text { or greater }\end{array}$ & \\
\hline & \multicolumn{5}{|c|}{ Any three of the above } \\
\hline
\end{tabular}

Table I. Differential criteria proposed by various expert groups to define Metabolic Syndrome

* Waist circumference: for Europeans, $>94 \mathrm{~cm}$ in men and > $80 \mathrm{~cm}$ in women; and for South Asians, Chinese, and Japanese, $>90 \mathrm{~cm}$ in men and $>80 \mathrm{~cm}$ in women. For ethnic South and Central Americans, South Asian data are used, and for sub-Saharan Africans and Eastern Mediterranean and Middle East (Arab) populations, European data are used.

$\mathrm{BMI}=$ Body Mass Index; $\mathrm{BP}=$ Blood Pressure; $\mathrm{IFG}=$ Impaired fasting glucose; HDL- C = High Density Lipoprotein-Cholesterol; TG $=$ Triglycerides $; \mathrm{WC}=$ Waist circumference $;$ WHR $=$ Waist Hip ratio

This current review focusses on efficacy of various existing dietary patterns for combating the syndrome along with other lifestyle risk factors. It also highlights newer advancements in the field of Metabolic Syndrome, which can serve as potential strategies to combat it. 


\section{Methodology}

In this article, we have reviewed existing literature regarding the current prevalence of MetS with focus on its relationship with diet as the most important modifiable factor. Besides this, relationship with other lifestyle factors and newer advancements to combat MetS has also been looked upon. Literature search was carried out using PubMed (National Library of Medicine, Bethesda, MD, USA), Medline, Cochrane Library, Science Direct, and Google Scholar databases. The keywords used were Metabolic Syndrome, diet, lifestyle, oxidative stress, gut microbiota, non-communicable diseases, prevalence, adults, inflammation and genetics. Published studies which have been listed in the above mentioned databases have been included in this review.

\section{Prevalence patterns of MetS in the developing world}

The prevalence of MetS is on the rise across the world. Twenty five percent of new cases of CVD are accounted by MetS. However according to the Framingham study in absence of DM, the risk of CVD is not increased by more than $20 \%$ (less than $10 \%$ for females, and between $10-20 \%$ for males) [21]. Variation in prevalence occurs with respect to sex, age and ethnicity [22,23]. MetS is even affecting the developing countries such as India and China. In India, urban Indians are most susceptible to its development owing to affluence of middle class, urbanization, mechanization, marked changes in diet (increased consumption of "calorie-dense foods") and sedentary habits [24], without overlooking the facet of rural Indian populations who are being affected by it as well [25-27]. This is an important matter, as without effective intervention strategies, it can lead to T2DM and CVD in future. Moreover, in comparison with Whites, South Asians exhibit CVD onset and diagnosis at a younger age [28]. The term "South Asian" refers to the "1.5 billion people belonging to the southern region of the Asian continent comprising the sub-Himalayan countries". These countries include India, Pakistan, Nepal, Sri Lanka, Bangladesh, Bhutan, Maldives, and the British Indian Ocean Territory [29].

In case of South Asians, MetS affects the migrants where its prevalence is around 20-25\% [30,31]. Specifically, in urban India, the prevalence of MetS was estimated by ICMR task force during 1992-94 in a collaborative study, according to which it was $30 \%$ in urban areas of Delhi and $11 \%$ in rural Haryana using the ATPIII criteria. Prevalence of 30\% in urban slum population of Delhi [5] and $41 \%$ in urban area of Chennai was reported among adults using modified ATPIII criteria [32]. The difference, though not completely, is characterized by usage of various definitions of MetS used and implies that prevalence across studies cannot be compared. These high prevalence rates in India especially among the urban population are of immediate concern, with cardiovascular prevention as its focal point.

A cross-sectional study of adults above the age of 18 years, conducted in the rural district of Wardha, Central India, delineated that MetS was significantly higher among females $(7.6 \%)$ in comparison to males (2.9\%) using the ATPIII guidelines for diagnosis. However, the prevalence notched up to $10.7 \%$ and $8.2 \%$ among males and females respectively when Asia Pacific guidelines modified for waist circumference were used [25]. MetS is also marked by gender differences owing to different cutoffs set for waist circumference and HDL values, hence, potentially significant for diagnosis and prevention $[33,34]$. Socio economic status has been shown to have association with the prevalence of MetS [3537]. Inverse relationship appears between MetS and socio economic status, more strongly for women in comparison to men in developed countries [36-40]. On the contrary, no association was seen with the overall prevalence of the metabolic syndrome and socio economic status in a subset of the participants $(\mathrm{n}=839)$ from the 1986 Jamaica Birth Cohort who were evaluated at ages 18-20 years. This absence of association was attributed to lack of statistical power [41]. However, in the developing countries, prevalence is marked by affluence. This difference across the countries is attributed to the available 
income for expenditure. In the developed countries, inverse association is accredited to the availability of low-cost energy dense foods that lead to insulin resistance to those with limited income. Moreover in women, low household income results in likely unemployment, reduced physical activity and stress, thus, leading to the syndrome [36]. In contrast, among developing countries, rise in income is associated with increase in consumption of foods high in energy and fat, animal foods and processed foods [42]. This leads to a great potential of poor health and subsequent development of MetS.

Considering age as an important determinant of MetS, a study to assess the prevalence of MetS in Iran was conducted with randomly selected adults $>20$ years selected using stratified sampling [43]. The prevalence was $23.7 \%$, being same in men and women. Significant age related increase was observed in both sexes ranging from $7.5 \%$ (20-29 year age group) to $44.7 \%$ (> 60 years of age). Other studies have also reported an increase in prevalence of the syndrome with age (Table II). Studies conducted in India using variable criteria to determine the MetS prevalence showed that in South Indian population, it was $25.8 \%$ using IDF as compared to $18.3 \%$ by ATPIII, in individuals $>20$ years of age [44]. Dissimilar trends were observed in Bangalore, where it was higher using the ATPIII criteria (40.3\%) as compared to IDF criteria (34.9\%) [18]. Prevalence studies in the rest of the world using different criteria have also demonstrated varying results (Table II). Engaging in different types of jobs is another important factor that has an implication in the development of MetS. Studies providing evidence for MetS have determined prevalence rates among laborers (11.8\%), office employees (9.3\%), and managers (7.7\%) [45].

\begin{tabular}{|c|c|c|c|c|}
\hline Design & Country & Sample & Salient Finding(s) & Reference \\
\hline Cross-sectional & Korea & $\begin{array}{c}\mathrm{N}=21,796 \text { (aged } 30 \text { years } \\
\text { and above) }\end{array}$ & $\begin{array}{l}\text { High prevalence was observed in housewives in } \\
\text { women (men } 41.3 \% \text {, women } 33.7 \% \text { ) and office } \\
\text { workers in men (men } 30 \% \text {, women } 9.8 \% \text { ) who } \\
\text { were the reference group to other occupations. }\end{array}$ & [46] \\
\hline Cross-sectional & Korea & $\begin{array}{c}\mathrm{N}=3,288 \text { (aged } 19 \text { years } \\
\text { and above) }\end{array}$ & $\begin{array}{c}\text { Prevalence of the syndrome among young female } \\
\text { workers ( }<50 \text { years) was high (OR=1.95) compared } \\
\text { to non-manual workers. }\end{array}$ & [47] \\
\hline Cross-sectional & Korea & $N=9,726$ & $\begin{array}{l}\text { Association between occupation and MetS was } \\
\text { observed in men but not in women. } \\
\text { Risk of the syndrome was high in white collar } \\
\text { workers compared to blue collar workers }(\mathrm{OR}=1.4) \text {. }\end{array}$ & [48] \\
\hline Cross-sectional & Iran & $\begin{array}{c}\mathrm{N}=429 \text { male bus and truck } \\
\text { drivers }\end{array}$ & $\begin{array}{l}\text { Prevalence }- \text { ATPIII criteria: } 35.9 \% \text {. } \\
\text { Positive correlation between BMI, DM, HT and } \\
\text { MetS }(p<0.001) \text {. } \\
\text { No positive correlation between smoking and MetS } \\
\quad(p<0.06) \text {. }\end{array}$ & [49] \\
\hline Cross-sectional & China & $\begin{array}{l}\mathrm{N}=3,953 \text { adults aged } \\
20-88 \text { years }(2,429 \\
\text { females, } 1,524 \text { males }) \text {. }\end{array}$ & $\begin{array}{l}\text { Prevalence - ATPIII criteria: men } 13.0 \% \text {, women } \\
15.3 \% \text {, who were alcohol drinkers. }\end{array}$ & [50] \\
\hline Cross-sectional & China & $\begin{array}{l}\mathrm{N}=2,334 \text { adults aged } 60 \text { to } \\
95 \text { years (943 men, } 1,391 \\
\text { women) }\end{array}$ & $\begin{array}{l}\text { Prevalence - ATPIII criteria: } 30.5 \% \text { ( } 17.6 \% \text { in men, } \\
39.2 \% \text { in women), IDF criteria: } 46.3 \% \text { ( } 34.8 \% \text { in } \\
\text { men, } 54.1 \% \text { in women). } \\
\text { Odds ratio for CVD, stroke and PAD are higher } \\
\text { among those with MetS (irrespective of criterion). }\end{array}$ & [51] \\
\hline Cross-sectional & China & $\begin{array}{l}\mathrm{N}=16,342 \text { subjects aged } \\
20-90 \text { years }(8,801 \text { males, } \\
7,541 \text { females })\end{array}$ & $\begin{array}{c}\text { Age-standardized prevalence of MetS was } 13.2 \% \text {. } \\
\text { Prevalence was more in males }(15.7 \%) \text { compared } \\
\text { to females }(10.2 \%) \text {. }\end{array}$ & [52] \\
\hline Cross-sectional & $\begin{array}{l}\text { Korea, } \\
\text { Japan }\end{array}$ & $\begin{array}{c}\mathrm{N}=6,824 \text { (aged } 20-79 \\
\text { years) }\end{array}$ & Prevalence - IDF criteria: men $13.5 \%$, women $15 \%$. & [53] \\
\hline
\end{tabular}




\begin{tabular}{|c|c|c|c|c|}
\hline Design & Country & Sample & Salient Finding(s) & Reference \\
\hline Cross-sectional & India & $\begin{array}{l}\mathrm{N}=19,973 \text { for } \\
\text { Questionnaire survey; } \\
\text { 10,442 biochemical testing } \\
\text { (Industrial population, } \\
\text { aged 20-69 years) }\end{array}$ & $\begin{array}{c}\text { Prevalence - ATPIII criteria: } 26.6 \% \text { (men } 20.9 \% \text {, } \\
\text { women } 36.3 \% \text { ); IDF criteria: } 35.4 \% \text { (men } 29.4 \% \text {, } \\
\text { women } 46.1 \% \text { ). }\end{array}$ & [54] \\
\hline Cross-sectional & Turkey & $\mathrm{N}=15,468$ adults & $\begin{array}{c}\text { Prevalence of MetS was } 17.91 \% \text {, being more in } \\
\text { females than males. } \\
\text { Prevalence of the syndrome and related disorders } \\
\text { are significantly different according to the } \\
\text { geographical region. }\end{array}$ & [55] \\
\hline Cross-sectional & $\begin{array}{l}\text { Korea, } \\
\text { Japan }\end{array}$ & $\begin{array}{c}\mathrm{N}=, 824 \text { (aged } 20-79 \\
\text { years) }\end{array}$ & $\begin{array}{c}\text { Prevalence - ATPIII criteria: men } 14.2 \% \text {, women } \\
17.7 \% \text {. } \\
\text { Moderate exercise }(2-3 \text { sessions/week }) \text { and light } \\
\text { alcohol drinking ( }<15 \mathrm{~g} / \mathrm{d}) \text { had inverse association } \\
\text { with MetS. }\end{array}$ & [56] \\
\hline Cross-sectional & Oman & $\begin{array}{c}\mathrm{N}=1,419 \text { adults }(\geq 20 \\
\text { years })\end{array}$ & $\begin{array}{l}\text { Age adjusted prevalence - ATPIII criteria: } 21.0 \% \\
\text { (men } 19.5 \% \text {, women } 23.0 \% ; p=0.236)\end{array}$ & [57] \\
\hline Cross-sectional & Australia & $\begin{array}{l}\mathrm{N}=5,850 \text { of which } \\
4,060 \text { had biochemical } \\
\text { examination }\end{array}$ & $\begin{array}{c}\text { Prevalence - IDF criteria: } 22.8 \text { (men } 26.4 \% \text {, women } \\
\text { 15.7\%); ATPIII criteria: } 15.0 \% \text { (men 19.4\%, } \\
\text { women } 14.4 \% \text { ) }\end{array}$ & [58] \\
\hline Cross-sectional & Greece & $\mathrm{N}=9,699$ adults & $\begin{array}{l}\text { Age adjusted prevalence - IDF criteria: } 43.4 \% \text {; } \\
\text { ATPIII criteria: } 24.5 \% \text {. } \\
\text { Lower vascular risk in those with IDF defined MetS } \\
\text { than with ATPIII defined }(p<0.0001)\end{array}$ & [59] \\
\hline Cross-sectional & Spain & $\mathrm{N}=1,030$ adults & $\begin{array}{c}\text { Age adjusted prevalence - WHO criteria: } 28.0 \% \text {; } \\
\text { EGIR criteria: } 15.9 \% \text {; NCEP criteria: } 23.0 \% \text {; Revised } \\
\text { NCEP criteria: } 28.2 \% \text {. } \\
\text { High prevalence of the syndrome irrespective of the } \\
\text { criteria used. }\end{array}$ & {$[60]$} \\
\hline Cross-sectional & Venezuela & $\begin{array}{l}\mathrm{N}=3,108 \text { men and women } \\
(\geq 20 \text { years })\end{array}$ & $\begin{array}{c}\text { Prevalence - ATPIII criteria: men } 31.2 \% \text {, women } \\
24.1 \% \text {. } \\
\text { Family history of diabetes, obesity, HT and } \\
\text { sedentary lifestyle were positively associated with } \\
\text { the MetS. }\end{array}$ & [61] \\
\hline Cross-sectional & U.S.A & $\begin{array}{c}\mathrm{N}=3,601 \text { adults }(>20 \\
\text { years })\end{array}$ & $\begin{array}{c}\text { Prevalence - ATPIII criteria: } 34.5 \% \text { (men } 33.7 \% \text {, } \\
\text { women } 35.4 \% \text { ); IDF criteria: } 39.0 \% \text { (men } 39.9 \% \text {, } \\
\text { women } 38.1 \% \text { ). }\end{array}$ & [62] \\
\hline Cross-sectional & Japan & $\begin{array}{l}\mathrm{N}=8,144 \text { individuals }(19- \\
88 \text { years })\end{array}$ & $\begin{array}{l}\text { Prevalence - ATPIII criteria: } 19 \% \text { men, } 7 \% \text { women. } \\
\text { Significantly more in men than women }(\mathrm{OR}=3.08) \text {. } \\
\text { HT was the most common component in all the } \\
\text { individuals diagnosed with the syndrome. }\end{array}$ & [63] \\
\hline Prospective & Mexico & $\begin{array}{l}N=2,282(1990-1992) \\
N=1,764(1993-1995) \\
N=1,754(1997-1999)\end{array}$ & $\begin{array}{c}\text { Prevalence - ATPIII criteria: 38.9\% (men 1990- } \\
\text { 1992), 43.4\% (men 1993-1995), 39.9\% (men } \\
\text { 1997-1999); 65.4\% (women 1990-1992), 65.7\% } \\
\text { (women 1993-1995), 59.9\% (women 1997-1999). } \\
\text { No change in syndrome's prevalence was observed } \\
\text { in men ( } p=0.349) \text { between 1990-1992 and 1997- } \\
\text { 1999, but it decreased in women ( } p<0.001) \text {. }\end{array}$ & {$[64]$} \\
\hline Cross-sectional & China & $\mathrm{N}=2,893$ & $\begin{array}{l}\text { Prevalence - ATPIII criteria: } 16.7 \% \text {. } \\
\text { Age related increase in the prevalence from } 3.1 \% \\
(25-29 \text { years) to } 41.0 \% \text { (>70 years). }\end{array}$ & {$[65]$} \\
\hline
\end{tabular}




\begin{tabular}{|c|c|c|c|c|}
\hline Design & Country & Sample & Salient Finding(s) & Reference \\
\hline Prospective & U.S.A & $\begin{array}{c}\mathrm{N}=6,436 \text { men and women } \\
\text { ( } \geq 20 \text { years) from NHANES } \\
\text { III (1988-1994) and } 1,677 \\
\text { participants from NHANES } \\
\text { 1999-2000 }\end{array}$ & $\begin{array}{l}\text { Age adjusted prevalence - ATPIII criteria: } 24.1 \% \\
\text { (NHANESIII), } 27.0 \% \text { (NHANES 1999-2000); } \\
\qquad p=0.088 \text {. } \\
\text { Increase in prevalence was more among women } \\
\quad(p=0.021) \text { than men }(p=0.831)\end{array}$ & [66] \\
\hline $\begin{array}{l}\text { Prospective, } \\
\text { Case-Control }\end{array}$ & U.S.A & $\begin{array}{c}\mathrm{N}=32,826 \text { women (cases) } \\
\text { and } \mathrm{N}=785 \text { (controls) }\end{array}$ & $\begin{array}{c}\text { Baseline levels of } T N F, I L \text {, and CRP were } \\
\text { significantly higher in cases than controls }(p \leq 0.001) \text {. } \\
\text { Significant association of } C R P \text { with risk of } D M \\
(O R: 3.99, p<0.001)\end{array}$ & [67] \\
\hline Cross-sectional & Finland & $\begin{array}{c}\mathrm{N}=2,049 \text { adults (FINRISK } \\
\text { study) aged } 45-64 \\
\text { years; } \mathrm{N}=522 \text { adults of } \\
\text { the Finnish Diabetes } \\
\text { Prevention Study (DPS) } \\
\text { with IGT }\end{array}$ & $\begin{array}{l}\text { Prevalence modified WHO criteria FINRISK cohort: } \\
38.8 \% \text { men, } 22,2 \% \text { women; DPS Cohort: } 78,4 \% \\
\text { men, } 72,2 \% \text { women. }\end{array}$ & [68] \\
\hline Cross-sectional & Greenland & $\mathrm{N}=917$ adults & $\begin{array}{l}\text { Prevalence - WHO criteria: } 20.7 \% \text {; ATPIII } \\
\text { criteria: } 17.9 \% \text {. } \\
\text { Moderate agreement between } 2 \text { definitions } \\
\qquad(\kappa=0.56) .\end{array}$ & [69] \\
\hline Cross-sectional & Tehran & $\begin{array}{l}\mathrm{N}=103,68 \text { adults }(4,397 \\
\text { men and } 5,971 \text { women) } \\
\text { aged } 20 \text { years and over }\end{array}$ & $\begin{array}{l}\text { Prevalence: } 33.7 \% \text {, increased with age in both } \\
\text { sexes. } \\
\text { MetS and its abnormalities were more common in } \\
\text { women in comparison to men }(p<0.001) \text {. }\end{array}$ & [70] \\
\hline Cross-sectional & U.S.A & $\begin{array}{c}\mathrm{N}=8,814 \text { men and women } \\
\text { (aged } 20 \text { years or older) }\end{array}$ & $\begin{array}{l}\text { Prevalence - ATPIII criteria: } 23.7 \% \text {. } \\
\text { Age related increase in prevalence was seen from } \\
20 \text { to } 29 \text { years and } 60 \text { to } 69 \text { years. }\end{array}$ & [23] \\
\hline Cross-sectional & Korea & $\begin{array}{c}\mathrm{N}=3,305 \text { black, } 3,477 \\
\text { Mexican American, and } \\
\text { 5,581 white men and } \\
\text { non-pregnant or lactating } \\
\text { women (aged } 20 \text { years } \\
\text { and older) }\end{array}$ & $\begin{array}{l}\text { Prevalence - ATPIII criteria: } 22.8 \% \text { men, } 22,6 \% \\
\text { women. } \\
\text { Mexican American ethnicity was more prone to } \\
\text { develop MetS. }\end{array}$ & [71] \\
\hline Cross-sectional & Irish & $\mathrm{N}=890$ (aged $50-60$ years) & $\begin{array}{l}\text { Combined prevalence according to WHO and } \\
\text { ATPIII criteria: } 13.1 \% \text {. } \\
\text { Age related increase in prevalence was seen. } \\
\text { Moderate correlation between both criteria } \\
\qquad(\kappa=0.53,0.46-0.60)\end{array}$ & {$[72]$} \\
\hline
\end{tabular}

Table II. Prevalence of MetS according to Age, diagnostic criteria and Occupation

ATPIII = Adult Treatment Panel III; BMI = Body Mass Index; CRP = C Reactive protein; CVD = Cardiovascular Disease; DM = Diabetes Mellitus; EGIR = European Group for the study of Insulin Resistance; HT =Hypertension; IDF =International Diabetes Federation; IL = Interleukin; NCEP = National Cholesterol Education Program; NHANES $=$ National Health and Nutrition Education Survey; TNF $=$ Tumor Necrosis Factor; WHO $=$ World Health Organization

Limitation nevertheless exists in the data published on the prevalence of MetS among adolescents and young adults. Estimates vary from $1 \%$ among adolescents in Japan (mean age-15 years), 6.4\% in United States (12-19 years), 6.5\% in Mexico (10-18 years) to $10 \%$ in Iran (10-19 years) [10,45]. Young adulthood is marked by transition from the carefree adolescent phase to a more responsible phase 
that brings along the pressure of finding new jobs and adjusting into them, coupled with changes in diet and lifestyle [73]. Though MetS portrays low prevalence among youth, clustering of risk factors can result in the progression towards the syndrome in adulthood, thus, advocating early identification for alleviation of the problems related to the syndrome is essential $[74,75]$. This holds true especially, in the Indian context, as the prevalence of all the individual components of the syndrome is on the rise.

\section{Causes and risk factors}

MetS is a challenging condition due to its varying definitions, cut-offs, and limited data for certain populations especially the young adults and elderly. It is not a discrete entity but consists of multitude of risk factors. The risk varies in an individual depending on the aggregation of metabolic and non-metabolic risk factors [13]. According to the AHA statement [13], atherogenic dyslipidemia, elevated blood pressure, and elevated plasma glucose are the most familiar risk factors. Abdominal obesity [71,76,77], insulin resistance [6,78], along with physical inactivity [71,79], aging [23], hormonal imbalance [80], and atherogenic diet (a diet rich in saturated fat and cholesterol) can exacerbate the risk for developing MetS, and consequently CVD [1]. Relationship of MetS with sex, age, degree of obesity and socioeconomic status has also been confirmed [81,82]. A solitary factor cannot purport to development of the syndrome; therefore, interaction amongst various domains relating to it, holds colossal worth that needs to be evaluated with the help of longitudinal studies [24].

\section{Diet and metabolic syndrome: a complex relationship}

Chronic diseases develop through a continuum from birth to adulthood with the interplay of genetics and environment. It has been gathered through the recent data that fetal/metabolic programming in utero due to poor maternal diet results in MetS, which is eventually responsible for all chronic diseases in future. Insulin resistance owing to thrifty genotype is the basic etiological factor leading to MetS. Though, the "Stone Age/Cave Man" diet of our hunter gatherer ancestors was far healthier from what we eat today; experience of alternate periods of abundance and scarcity during that time, led to an adaptive trait to survive the situation resulting in quick insulin release and lipid synthesis during starvation, to provide energy. However, with the advent of agriculture and urbanization, current diets have changed extremely from being healthy to those that are rich in saturated fat and cholesterol, which coupled with sedentary lifestyle leads to rapid glucose release and eventually positive energy balance. Whereas on one hand, thrifty genotype lead to increased survival chances with meager food supply, in times of abundant food availability it has led to development of chronic diseases and sedentary lifestyle [83]. Therefore, it emerges that faulty diet is a major root-cause of the problem and is the preventive measure that needs to be taken to ameliorate MetS or at least reduce its prevalence.

\section{Effective dietary patterns}

\section{Mediterranean diet}

A dietary pattern consisting of fruits, vegetables, whole grains, legumes, and fish, dairy products, wine and nuts in moderation is categorized as the Mediterranean Dietary pattern. When taken appropriately and adhered to properly, it results in improvement of health and quality of life [84]. The efficacy of Mediterranean diet on MetS has been observed through many studies [85-89]. However, when the Mediterranean dietary pattern is not strongly adhered, there are no changes in the metabolic risk factors. Fruit, vegetables, cereals, whole fat dairy products, MUFA and moderate alcohol intake in the form of 
red wine had a protective effect, while intake of red meat resulted in increased risk [90]. Similar results with respect to red meat were indicated in the Oxford EPIC cohort [91] with more than 11000 subjects aged 20-79 years, wherein, no consumption of meat, fish, eggs or dairy products resulted in decrement in the blood pressure levels by $2-4 \mathrm{mmHg}$ compared to regular meat consumers.

Incidence in the reduction of MetS can be brought about with proper diet strategies incorporating the components of Mediterranean diet [92] such as adequate consumption of omega-3 fatty acids, reduction of saturated and trans fats, and high intake of fruits, vegetables, whole grains, and nuts (Table III). In a randomized control trial, the experimental group following a prudent dietary pattern over a period of 2 years in Naples ( $\mathrm{n}=180)$ (Italy), resulted in reduction of 55.6\% in prevalence of MetS compared to $13.3 \%$ reduction in the control group. A meta-analysis of 12 studies with more than 1.5 million individuals tracked for 3-18 years for their health and health habits [93] demonstrated the effectiveness of Mediterranean diet in age related morbidity conditions especially MetS, CVD (pooled relative risk 0.91 ) and overall mortality (pooled relative risk 0.91 ), as has been proven over time94. Rumawas et al. [87] examined prospectively association between the Mediterranean-style dietary pattern and metabolic syndrome in the Framingham Heart Study Offspring Cohort for 2730 participants, out of which 378 diabetic patients and 318 patients reporting missing information were excluded, being followed up for 7 years. Prudent dietary pattern - rich in whole grains, fruit, vegetables, nuts, and omega-3 fatty acids and low in refined grains and saturated and trans fats, has revealed to propose a substantial protection against heart disease.

\begin{tabular}{|c|c|c|c|c|}
\hline Design & Country & Sample & Salient Finding(s) & Reference \\
\hline RCT & U.S.A & $\begin{array}{l}\text { Control: } \mathrm{N}=44 \text { women } \\
\text { (Mediterranean-style } \\
\text { low-glycemic-load diet). } \\
\text { Intervention: } \mathrm{N}=45 \\
\text { women (diet }+ \text { medical } \\
\text { food containing } \\
\text { phytosterols, soy } \\
\text { proteins) }\end{array}$ & $\begin{array}{c}\text { Decreases in fat and sugar intake }(p<0.001) \text {, and } \\
\text { increase in DHA and EPA ( }<<0.001) \text { were observed in } \\
\text { both groups. } \\
\text { Significant reduction in all components of MetS }(p<0.05) \\
\text { and plasma homocysteine levels was seen in the diet + } \\
\text { medical food group }(p<0.01) \text { as compared to diet only } \\
\text { group. }\end{array}$ & [86] \\
\hline Prospective & U.S.A & $\mathrm{N}=2,730$ adults & $\begin{array}{l}\text { Significantly lower incidence of MetS was seen among } \\
\text { those following a Mediterranean style dietary pattern } \\
\qquad(p=0.01) \text {. } \\
\text { Mediterranean diet also led to significant lowering of } \\
\text { waist circumference }(p<0.001) \text {, fasting plasma glucose } \\
(p=0.03) \text {, and triglycerides }(p<0.001) \text { and higher HDL } \\
\text { cholesterol }(p=0.02) .\end{array}$ & [87] \\
\hline RCT & Iran & $\begin{array}{c}\mathrm{N}=100 \text { obese } \\
\text { adolescents (aged 12- } \\
18 \text { years) }\end{array}$ & $\begin{array}{c}\text { Significant decrease in weight after } 3 \text { months of } \\
\text { intervention }(p<0.05) \text { in the intervention group. } \\
\text { Significant decrease in BMI and increase in fruit and } \\
\text { vegetable consumption was seen in the intervention } \\
\text { group. }\end{array}$ & [88] \\
\hline RCT & Germany & $\begin{array}{c}\mathrm{N}=101 \text { adults }(\mathrm{N}=48 \\
\text { med diet group }+100 \\
\text { hrs of education vs } \\
\mathrm{N}=53 \text { written advice } \\
\text { only group) }\end{array}$ & $\begin{array}{l}\text { Increase in the consumption of fish, fruits/vegetables } \\
\text { and moderately of canola/olive oil and increased plasma } \\
\text { concentrations of long-chain n-3 polyunsaturated fatty } \\
\text { acids. } \\
\text { No change in the markers of inflammation like hs-CRP, } \\
\text { fibrinogen, fasting insulin, homocysteine, serum lipids } \\
\text { and plasma fatty acids }\end{array}$ & [89] \\
\hline
\end{tabular}




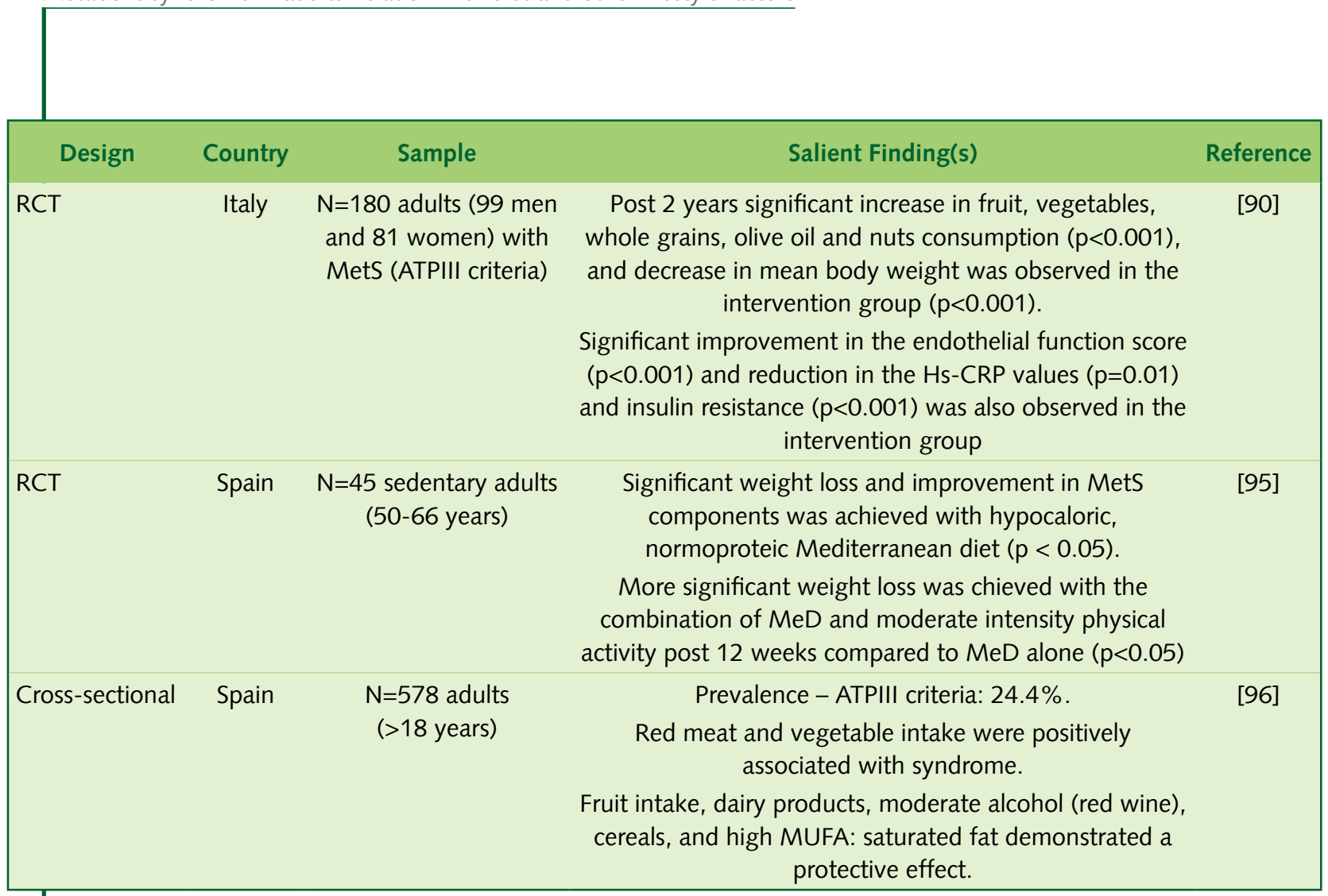

Table III. Role of Mediterranean diet in the improvement of MetS

$\mathrm{BMI}=$ Body Mass Index; $\mathrm{CRP}=\mathrm{C}$ Reactive Protein; $\mathrm{DHA}=$ Docosa Hexanoic Acid; EPA = Eicosa Pentanoic Acid; $\mathrm{MeD}=$ Mediterranean Diet; MUFA = Mono Unsaturated Fatty Acid

Specifically, each component of Mediterranean dietary pattern has its own significance that holds a key in obviating MetS. In the Bogalusa heart study, 1420 subjects aged 19-38 years were followed to make comparisons in the dietary intake of those who suffered from the syndrome with those who didn't [97]. MetS was evident in $12 \%$ of the young population (NCEP ATPIII criteria). Dietary patterns revealed consumption of fruits, fruit juices, vegetables, low-fat dairy products, diet beverages, less sweetened beverages and alcohol among those with no risk factors. No relation was found for red meats or processed meats. Thus, poor fruit and vegetable consumption and high consumption of sweetened beverages can serve as independent risk factors for MetS.

The Mediterranean diet can be considered a function of the prudent dietary pattern; however, its relation with insulin resistance and metabolic risk factors for CVD in non-Mediterranean populations is largely unexplored. Another meta-analysis of 50 studies and 534,906 individuals to ascertain the effect of Mediterranean diet on MetS and its components has come up with findings from prospective studies, clinical trials as well as epidemiological trials, that it is beneficial in the reduction of the syndrome [98]. Therefore, Mediterranean diet as a function of the prudent dietary pattern has shown its beneficial effects in the improvement of MetS substantially as projected by the evidence gathered through the years. Certain studies have demonstrated that high intake of saturated fatty acids [99-101] and low intake of n3 fatty acids [102] are responsible for MetS. Dairy products being a rich source of calcium have also shown to be beneficial in reducing the risk of blood pressure [103,104] MetS (Table IV), coronary heart disease [105], and inversely related to BMI. In a prospective study by Azadbakht et al. [106], it was seen that high intake of dairy was associated inversely with MetS, enlarged waist circumference and hypertension. The beneficial effect of the dairy products has been attributed by the presence of calcium in them that mediates the process of reducing the incidence of adiposity, hypertension and CVD, as 
reported by various researchers [107-110]. Similar results with dairy calcium have been shown by Lin et al. [111]. They proposed that weight loss was more with dairy rich diets than calcium rich diets alone, which can also be due to the anti-obesity effect of protein in it [112]. A cross sectional study showed the same effect with calcium, however, some confounding factors such as physical activity, intake of fruits and vegetables were not taken into account [113]. In a 10 year long prospective study comparisons were made with respect to the amount of dairy intake and its ability to reduce the incidence of MetS [114]. However, similar causal reduction in the MetS incidence was not noticed in this study.

\begin{tabular}{|c|c|c|c|c|}
\hline Year & Design & Sample & Finding & Reference \\
\hline 2009 & Intervention & $\begin{array}{l}\mathrm{N}=153 \text { obese adults with MetS } \\
\text { randomised to intervention or } \\
\text { control for } 16 \text { weeks }\end{array}$ & $\begin{array}{l}\text { Significant improvement observed in body } \\
\text { composition }(p<0.01) \text {, physical and cardio- } \\
\text { metabolic fitness }(p<0.01) \text { with minimally } \\
\text { prescriptive lifestyle intervention program. }\end{array}$ & [115] \\
\hline 2005 & Cross-sectional & $\begin{array}{l}\mathrm{N}=827 \text { subjects }(357 \text { men, } 470 \\
\text { women); } 18-74 \text { years }\end{array}$ & $\begin{array}{l}\text { Inverse association of diary consumption } \\
\text { with MetS }(p<0.02), W C(p<0.001) \text { and } \\
\qquad H T(p<0.02)\end{array}$ & [106] \\
\hline 2005 & Cross-sectional & $\begin{array}{l}\mathrm{N}=34 \text { hyperlipidemic men and } \\
\text { women }\end{array}$ & $\begin{array}{l}\text { Reduction in CRP was observed with } \\
\text { cholesterol lowering diet }(p=0.001) \text { and statins } \\
\qquad(p=0.013)\end{array}$ & [116] \\
\hline 2005 & Cross-sectional & $\mathrm{N}=11,686$ women; $\geq 45$ years & $\begin{array}{l}\text { Mg intake was inversely associated with CRP } \\
\qquad(p<0.0001) \text { and MetS }(p=0.0008)\end{array}$ & [117] \\
\hline 2003 & $\begin{array}{l}\text { NHANES survey } \\
\text { (prospective) }\end{array}$ & $\begin{array}{l}\mathrm{N}=17,030,20 \text { years or older } \\
\text { both men and women }\end{array}$ & $\begin{array}{l}\text { Higher Ca intake led to lower age-related } \\
\text { increase in blood pressure }(p<0.001) \text {. }\end{array}$ & [103] \\
\hline 2002 & Cross-sectional & $\begin{array}{c}\mathrm{N}=192 \text { individuals with MetS } \\
\text { and } 384 \text { disorder-free control } \\
\text { subjects, matched by age and } \\
\text { gender }\end{array}$ & $\begin{array}{l}\text { Inverse association between serum } M g \text { levels } \\
\text { and MetS }(O R=6.8) \text {, dyslipidemia }(O R=2.8) \\
\text { and high blood pressure }(O R=1.9)\end{array}$ & [118] \\
\hline 2002 & Prospective & $\begin{array}{l}\mathrm{N}=3,157 \text { black and white adults } \\
\text { (18-30 years) }\end{array}$ & $\begin{array}{l}\text { Inverse association of dairy products } \\
\text { consumption with MetS in overweight adults } \\
(\mathrm{OR}=0.79) \text {. }\end{array}$ & [114] \\
\hline 2003 & Cross-sectional & $\begin{array}{l}\mathrm{N}=27,862 \text { apparently healthy } \\
\text { men and women ( } 25-82 \text { years) }\end{array}$ & $\begin{array}{l}\text { Positive association of protein intake with BMI } \\
\text { and weight gain/obesity. }\end{array}$ & [112] \\
\hline 2001 & Prospective & $\mathrm{N}=5,765$ men (35-64 years) & $\begin{array}{l}\text { No association between milk consumption and } \\
\text { CVD mortality. }\end{array}$ & [105] \\
\hline 2000 & Cross-sectional & $\begin{array}{l}\mathrm{N}=7,543 \text { men and } 8,053 \\
\text { women }(25-69 \text { years })\end{array}$ & $\begin{array}{l}\text { Negative association between } C a \text { intake and } \\
\text { blood pressure in both sexes }(p<0.05) \text {. }\end{array}$ & [104] \\
\hline 2000 & $\begin{array}{l}\text { Prospective } \\
\quad(\mathrm{RCT})\end{array}$ & $\begin{array}{l}\mathrm{N}=54 \text { normal weight young } \\
\text { women (18-31 years) }\end{array}$ & $\begin{array}{l}\text { High } \mathrm{Ca} \text { intake led to lower weight gain and } \\
\text { body fat after } 2 \text { years of intervention. }\end{array}$ & [111] \\
\hline 2000 & Cross-sectional & $\begin{array}{l}\mathrm{N}=2,537 \text { women and } 2,439 \\
\text { men }\end{array}$ & $\begin{array}{l}\text { Inverse association between dairy products and } \\
\text { bread consumption and MetS in men. }\end{array}$ & [113] \\
\hline 1998 & Cross-sectional & $\begin{array}{c}\mathrm{N}=180 \text { postmenopausal women } \\
\text { (45-64 years), and } 197 \text { men } \\
\text { (30-64 years ) }\end{array}$ & $\begin{array}{l}\text { Both diet and exercise together led to decrease } \\
\text { in the LDL levels after } 1 \text { year among women } \\
\qquad(p<0.05) \text { and men }(p<0.01)\end{array}$ & [119] \\
\hline
\end{tabular}

Table IV. Relationship between dairy products and MetS

$\mathrm{BMI}=$ Body Mass Index; $\mathrm{Ca}=$ Calcium; CRP = C Reactive Protein; CVD = Cardiovascular Disease;

$\mathrm{HT}=$ Hypertension; LDL = Low Density Lipoprotein; Mg = Magnesium; WC = Waist Circumference;

MetS $=$ Metabolic Syndrome 
Various epidemiological studies have suggested that magnesium can be an independent risk factor for the development of DMT2 [120-122], being a co-factor in number of enzymatic reactions that regulate glucose metabolism and insulin homeostasis $[123,124]$. In a cross-sectional study, an inverse association was reported between serum magnesium levels and MetS [118]; similar relationship was also seen with dietary magnesium intake [117]. In the CARDIA study, a total of 608 cases with MetS were identified in young adults (18-30 years; $n=4637$ ), wherein, magnesium intake was found to be inversely associated with it. Of particular significance, were the inverse associations of magnesium with blood pressure and triglycerides which were subsequently attenuated with lifestyle and dietary factors adjustment [51]. But the important question which arises is that, will a higher intake of magnesium prevent MetS? A question which can only be answered with more data from randomized control trials.

\section{Vegetarian dietary pattern}

The type of diet consumed also has various implications on MetS. A vegetarian diet consists of mostly food items that are from plants and plant products and does not have items resulting from death of animals. However, they may consume dairy products, milk and eggs [125]. The vegetarian dietary pattern can further be subdivided into lacto-ovo vegetarian (consuming milk, dairy products and eggs), lacto vegetarian (consuming milk and dairy products) and vegans (consuming no animal product). This vegetarian dietary pattern has shown to lower the risk of MetS. Rizzo et al. [126] studied various dietary patterns and looked at their association with MetS and its risk. Among subjects $(n=773)$ of 30-94 years of age, dietary intake was assessed using a quantitative self-administered food frequency questionnaire and classified them into three categories - as vegetarian (consuming meat, poultry or fish $<1$ time in a month), semi-vegetarian (consuming fish at any frequency but other meats $<1$ time in a month), and non-vegetarians (consuming red meat or poultry $\geq 1$ time/month). BMI was lowest in vegetarians and highest in non-vegetarians. MetS was classified according to the ATPIII criteria, with maximum number of components (i.e.5) for non-vegetarians. TG, FBG, BP, WC and BMI was significantly lower in vegetarians as compared to non-vegetarians $(\mathrm{p}<0.05)$. MetS was highest in non-vegetarians $(39.7 \%)$, followed by semi-vegetarians (37.6\%) and vegetarians (25.2\%); with vegetarians having a lower odds for developing the syndrome (OR-0.44; $\mathrm{p}<0.001)$. Similar findings [127] were observed in case of male and female vegans and lacto-ovo vegetarians; with significantly lower BMI, TG level, TC/HDL ratio among vegans as compared to lacto-ovo vegetarians $(\mathrm{p}<0.05)$. Vegans also demonstrated more favorable serum lipid profile as compared to lacto-ovo vegetarians.

De Baise et al. [128] tried to compare levels of TG, LDL-cholesterol and HDL-cholesterol between vegetarians (lacto-ovo vegetarians $[n=19]$, lacto vegetarians $[n=17]$ and vegans $[n=18]$ ) and omnivores $(n=22)$. For the same, blood samples were drawn from 76 adults and it was observed that there was a significant difference for these biochemical parameter values among all groups except for HDLcholesterol. HDL/TC ratio was significantly higher in vegans ( $<<0.01$ ), while TC and LDL-cholesterol values were highest for omnivores as compared to vegans $(\mathrm{p}<0.001)$. Cardiovascular risk [125] was also ascertained in a cohort of 201 individuals (35-64 years) in Brazil after classifying them as vegetarians $(n=67)$ and omnivores $(n=134)$. Levels of BP, FBG, TG, TC and LDL-cholesterol were significantly lower among vegetarians $(\mathrm{p}<0.001)$ except for HDL-cholesterol which showed no difference. Overall, vegetarians had a significantly lower cardiovascular risk $(\mathrm{p}<0.001)$ compared to omnivores whose diet consisted of animal protein and more fat.

Various studies related specifically to the Indian dietary pattern have shown risk for MetS and eventually CVD [129]. Whereas consumption of dairy foods, fried snacks and sweets consumption was associated positively with abdominal obesity; inverse relationship was observed with vegetables and pulses consumption for DM and hypertension. Vegetable and mustard oil consumption has also been proven beneficial [130]. The risk factors were more prevalent among the South Indians than North Indians [131]. 


\section{Other lifestyle risk factors}

\section{Alcohol}

Moderate alcohol consumption exerts a protective effect on MetS. Specifically, red wine consumption (0.1-19.9 g/day) resulted in a two-fold decrease in the prevalence of high blood pressure among women compared to non-consumers [132]; and has also been shown to improve the CVD risk profile in a Spanish population based study [133]. In the National heart study and DESIR French study, higher HDL values were observed in alcohol consumers. The underlying mechanism of this protective effect is the direct effect that alcohol has on HDL cholesterol synthesis, by modifying the activity of lipoprotein lipase, hepatic lipase, and cholesterol-esterase [134].

Inverse association of HDL cholesterol, triglycerides and blood pressure with alcohol consumption has an impact on the MetS $[134,135]$. Alcohol consumption of less than $40 \mathrm{~g} /$ day for men and less than 20 $\mathrm{g} /$ day for women suggested lower prevalence of MetS in comparison to non-alcoholics, as demonstrated by a meta-analysis of seven observational studies136. Protective effect in wine drinking women $(\mathrm{n}=4232)$ with lower odds ratio of syndrome development $(\mathrm{OR}=0.60, \mathrm{p}<0.05)$ has been seen compared to men in Sweden [137]. Opposing to this, are detrimental effects in case of heavy alcohol consumption such as increase in waist circumference, triacylglycerols, blood pressure, and glucose, thus, augmenting the risk of metabolic syndrome [135,138-140].

\section{Smoking}

Studies have indicated that smokers have a higher risk of becoming insulin resistant, hence, smoking can be considered as a modifiable risk factor for MetS [141,142]. In a cross-sectional study of 3452 men, $\geq 20$ years of age from a nationally representative sample of Koreans, a positive association between smoking and MetS was found [143]. Statistically significant association of current smoking amounts $(\mathrm{p}=0.023)$, total packs of cigarettes smoked during lifetime $(\mathrm{p}=0.040)$, with MetS, indicated smoking as an independent factor for the syndrome [144]. Evidence generated from different population groups has also supported the relation of smoking with hypertension [145,146] and type 2 diabetes [147,148].

With limited data on early identification of indicators of MetS before the development of the syndrome, a pilot study by Corwin et al. [149] estimated the risk scores in 41 subjects aged 18 to 39 years with 20 smokers and 21 non-smokers for three indicators: cardiovascular, metabolic, and immune related. Total risk scores were significantly greater in men $(\mathrm{p}=0.02)$ compared to women with only mixed effects of cigarette smoking. Similar effects of smoking on MetS have also been demonstrated by earlier studies $[141,142,144]$. Therefore, interventions focusing on modifiable risk factors should be undertaken.

\section{Newer advancements}

\section{Oxidative stress}

With still so many defining criteria for diagnosis of MetS, and an unclear picture on its pathophysiology, there is still uncertainty about the concept of syndrome as a whole. It is characterized by altered antioxidant status and sub-clinical inflammation, and has shown association with oxidative stress [150]. Therefore, a combined condition of hyperglycemia and inflammation (both characteristics of MetS), leads to increased production of reactive oxygen species and eventually increased oxidative stress. The main reactive oxygen species generated is super oxide anion which is produced by NADPH oxidase [151]. Oxidative damage occurs as a result of enzymatic and non-enzymatic components (vitamins E and C), and in case of physiological conditions, cells exhibit anti-oxidative mechanism to counteract the damage. However, when there is increased production of reactive oxygen species, balance between 
enzymatic and non-enzymatic components is disturbed leading to a pro-oxidative condition [150]. Specifically, in MetS, there is decrease in both enzymatic components as well as in the levels of vitamin $\mathrm{C}$ and $\mathrm{E}$ due to decreased total antioxidant status [151,152], which eventually leads to increased oxidative stress proportionally [153]. Thus, has emerged the role of measurement of plasma oxidative stress which can identify MetS patients who are at an increased risk and those who may require intensive treatment.

\section{Gut microbiota}

Environment and epigenetics are two important factors that need to be considered in the origin of metabolic diseases as can be seen with gradual transition in eating habits, and increased consumption of fatty diets. However, it is still an unexplained concept as to why some people are sensitive and other resistant to metabolic disorders such as obesity and diabetes; therefore, individuality is an important concept that needs to be provided attention to. Therefore, four main factors emerge that are often overlooked in development of metabolic diseases-genetics, environment, individuality and rapid development of metabolic diseases. In this regard, role of intestinal and tissue microbiota is emerging that is linked to the development of metabolic diseases such as obesity and diabetes. The molecular mechanism underlying hyperglycemia and increased body weight have been related to inappropriate energy expenditure. In case of T2DM, there is increased hepatic glucose production and decreased insulin action and secretion; whereas in case of obesity, there is actually decreased requirement of food intake and energy expenditure, so when that does not occur, molecular factors lead to adipose tissue development and body weight gain [154]. A newer concept explaining it describes that having a fatty meal triggers bacterial factors that cause modification in intestinal microbiota and enter the host through innate immune system, triggering inflammation [155]. These bacteria then go to metabolic tissues such as adipose tissue and liver. Inflammatory mediators impair insulin secretion and lead to more adipose tissue development. Therefore, treatment targeting at the right bacterial translocation for therapies or prevention of metabolic diseases is important. Various trials on mice have demonstrated the use of probiotics such as bifidobacterium lactis B420 in preventing insulin resistance [156].

Immune system and its changes lead to rapid increase in metabolic disorders; hence, it becomes all the more important to understand interaction between immune system and microbiota in order to know the underlying process in the development of metabolic diseases.

\section{Early roots of Metabolic Syndrome: critical window of intervention}

MetS has its roots early in life starting from the mother's womb itself. Intrauterine growth has positive relationship with the syndrome's occurrence. In the Atherosclerosis Risk in Young Adults (ARYA)-study, 744 young adults aged 26-31 years, were tracked on their birth weight [157]. Findings of the study revealed that those who were in the lower tertile of birth weight $(1,250-3,209$ and 3,210-3,649 $\mathrm{g})$ had 1.8 times greater risk of developing MetS compared to those in the highest tertile (3,650-5,500 g). The syndrome is on the rise among young adults [158,159], with its roots embedded early in life [160-164]. A cohort of healthy young individuals in Amsterdam was followed for 24 years from the age of 13 years to 36 years to ascertain the prevalence of MetS (NCEP-ATPIII criteria) in relation to fatness, fitness and lifestyle. The prevalence was estimated as $10.4 \%$ (18.3\% in men and $3.2 \%$ in women) at 36 years of age. Significant increases in the BMI and skinfold(s) ratio, compared to a significant decrease in the cardiopulmonary fitness was observed from adolescence to adulthood in adults with MetS, particularly at the ages of $21,27,32$, and 36 years. Similar likelihood towards higher energy intake was observed throughout the years [165]. 
Prevalence of the MetS is widespread in Asia, with India contributing 30\% of it [30]. However, according to the theory of developmental origin of health and disease, thrifty gene hypothesis is substantiated to be the underlying factor for the syndrome [166]. The triad of low birth weight and stunting due to malnutrition in early life availability of energy-dense foods at a later age in life, and sedentary habits, eventually leading to obesity with alteration in the body composition in terms of fat deposition, insulin resistance, and diet related chronic diseases [83]. MetS continues to evolve over a period of lifetime as evident in case of Delhi birth cohort which indicated prevalence of CVD risk factors highest among the ages of 29-36 years [167]. Young adulthood is a critical period to target intervention strategies that prevent excess weight gain and central fat deposition. Public health interventions targeting young people by focusing on the modifiable risk factors for the syndrome like weight control and regular physical activity can go a long way in restraining the development of DMT2 and CVD in future [165].

\section{Conclusion}

The problem of MetS is inevitable especially in a country like India, being a major public health challenge [83]. Given the magnitude of the problem, the public health responses should be strong, committed and focused both on primary and secondary prevention. Since, it is an emerging problem, the most important way of combating it, is to reduce its incidence by preventing its complications from developing. Prevention, by means of education - of both health professionals and public regarding healthy diet and lifestyle is required $[168,169]$. This will ensure minimization of health services cost to achieve maximum benefit to tackle this problem with available resources on a long term basis. Moreover, the rationale behind the therapeutic strategy for treatment of MetS highlights the fact that it is essential to correct insulin resistance, hyperinsulinimea and other metabolic abnormalities [170]. Therefore, the emphasis needs to be laid on comprehensive lifestyle change including both diet and physical activity; wherein, diet quality holds prime importance. Measurement of plasma oxidative stress and therapies targeting gut microbiota are current advancements in the field of MetS that are needed to be incorporated as strategies for early prevention of the syndrome. With long term management and regular follow up, the lifetime risk of MetS can be substantially reduced [13]. The need of the hour is to create awareness among treating physicians as well as the people regarding early diagnosis and comprehensive treatment as well as prevention of all components of MetS in an "available, accessible and affordable" manner. Therefore, adoption of healthy diets such as the Mediterranean and vegetarian diet along with changes in lifestyle including regular physical activity and foregoing smoking and alcohol can be of utmost public health importance, as these changes are not only cost-effective for primary and secondary prevention of MetS, but feasible to implement by all population groups and various cultures.

Questions for further research

MetS is a complicated disorder that is increasing at an alarming rate. Prevention is the best way to reduce the incidence of the syndrome. Though studies have focused on modifying various risk factors such as diet, alcohol, smoking and physical activity; diet overweighs all the other factors in terms of its magnitude as well as its relationship with the syndrome. Future research needs to be carried out to identify newer dietary patterns or dietary modifications which have a potential to combat the syndrome. Newer techniques for identifying at-risk patients should also be developed which can go a long way in reducing the burden of disease as well as the increased healthcare costs that it imposes on the nations. 


\section{The review in brief}

$\begin{array}{ll}\text { Clinical question } & \begin{array}{l}\text { Faulty diet is one of the major root causes of Metabolic Syndrome and needs maximum attention, as it } \\ \text { can reduce the incidence of the syndrome. The present review assesses the efficacy of various existing } \\ \text { dietary patterns for combating the syndrome. }\end{array} \\ \text { Type of review } & \text { Narrative } \\ \text { Search of the } & \text { PubMed (National Library of Medicine, Bethesda, MD, USA), Medline, Cochrane Library, Science Direct } \\ \text { literature } & \begin{array}{l}\text { and Google Scholar databases. The keywords used were Metabolic Syndrome, diet, lifestyle, oxidative } \\ \text { stress, gut microbiota, non-communicable diseases, prevalence, adults, inflammation and genetics. }\end{array} \\ \text { Conclusions } & \begin{array}{l}\text { The present review concludes that: } \\ \text { - }\end{array} \\ \text { - MetS is a major public health challenge. } & \text { The best way to combat it is to prevent it. } \\ \text { - Prudent dietary patterns such as the Mediterranean diet and the vegetarian diet are protective in } \\ \text { nature and have shown their efficacy to reduce the syndrome. } \\ \text { - Oxidative stress measurement is an emerging technique to identify MetS patients at increased risk. } \\ \text { - Role of gut microbiota is also important in identifying the syndrome; however, it is still a newer concept. } \\ \text { - Early intervention is the need of the hour. } \\ \text { - Preventive strategies for MetS should be acceptable, affordable, feasible and most importantly } \\ \text { sustainable. } \\ \begin{array}{l}\text { Studies have shown that dietary modification can go a long way in preventing the syndrome. However, } \\ \text { only a few dietary patterns have been identified in this regard. More research needs to be carried out } \\ \text { to explore and identify newer dietary modifications that can reduce the syndrome or prevent it. Public } \\ \text { health programs should focus on prevention through education but emphasis needs to be laid on } \\ \text { developing programs that ensure sustainability. }\end{array} \\ \text { Limitations }\end{array}$

\section{References}

1. National Cholesterol Education Program (NCEP) Expert Panel on Detection, Evaluation, and Treatment of High Blood Cholesterol in Adults (Adult Treatment Panel III). Third Report of the National Cholesterol Education Program (NCEP) Expert Panel on Detection, Evaluation, and Treatment of High Blood Cholesterol in Adults (Adult Treatment Panel III) final report. Circulation 2002; 106: 3143-21

2. Hanley AJ, Festa A, D’Agostino RB Jr, et al. Metabolic and inflammation variable clusters and prediction of type 2 diabetes: factor analysis using directly measured insulin sensitivity. Diabetes 2004; 53 :1773-81; http://dx.doi.org/10.2337/diabetes.53.7.1773

3. McKeown NM, Meigs JB, Liu S, et al. Carbohydrate nutrition, insulin resistance, and the prevalence of the metabolic syndrome in the Framingham Offspring Cohort. Diabetes Care 2004; 27: 538-46; http://dx.doi.org/10.2337/diacare.27.2.538

4. Kassi P, Kaltsas G, Chrousos G. Metabolic syndrome: definitions and Controversies. BMC Med 2011; 9: 48; http://dx.doi.org/10.1186/1741-7015-9-48

5. Misra A, Pandey RM, Devi JR, et al. High prevalence of diabetes, obesity and dyslipidaemia in urban slum population in northern India. Int J Obes Relat Metab Disord 2001; 25: 1722-9; http:// dx.doi.org/10.1038/sj.ijo.0801748

6. Reaven GM. Banting lecture. Role of insulin resistance in human disease. Diabetes 1988; 37: 1595607; http://dx.doi.org/10.2337/diab.37.12.1595

7. Kahn R, Buse J, Ferrannini P, et al. The Metabolic Syndrome: Time for a Critical Appraisal Joint statement from the American Diabetes Association and the European Association for the Study of Diabetes. Diabetes Care 2005; 28: 2289-304; http://dx.doi.org/10.2337/diacare.28.9.2289 
8. Alberti KG, Zimmet PZ. Definition, diagnosis and classification of diabetes mellitus and its complications, part 1: diagnosis and classification of diabetes mellitus provisional report of a WHO consultation. Diabet Med 1998; 15: 539-53; http://dx.doi.org/10.1002/(SICI)10969136(199807)15:7<539::AID-DIA668>3.0.CO;2-S

9. Balkau B, Charles MA. Comment on the provisional report from the WHO consultation. European Group for the Study of Insulin Resistance (EGIR). Diabet Med 1999; 16: 442-3; http://dx.doi. org/10.1046/j.1464-5491.1999.00059.x

10. National Institutes of Health: Executive summary. In Third Report of the National Cholesterol Education Program Expert Panel on Detection, Evaluation, and Treatment of High Blood Cholesterol in Adults (Adult Treatment Panel III). Washington, DC, U.S. Govt. Printing Office (NIH publ. no. 01-3670), 2001

11. Bloomgarden ZT. American Association of Clinical Endocrinologists (AACE) Consensus Conference on the Insulin Resistance Syndrome. Diabetes Care 2003; 26: 933-9; http://dx.doi. org/10.2337/diacare.26.3.933

12. International Diabetes Federation. The IDF consensus worldwide definition of the metabolic syndrome, 2005. Avilable at: http://www.idf.org/webdata/docs/Metabolic_syndrome_definition. pdf (last accessed 12 March 2015)

13. Grundy SM, Cleeman JI, Daniels SR, et al. Diagnosis and Management of the Metabolic Syndrome: An American Heart Association/National Heart, Lung, and Blood Institute Scientific Statement. Circulation 2005; 112: 2735-52; http://dx.doi.org/10.1161/CIRCULATIONAHA.105.169405

14. Do Carmo I, Dos Santos O, Camolas J, et al. Overweight and obesity in Portugal: National prevalence in 2003-2005. Obes Rev 2008; 9: 11-9

15. Hollman G, Kristenson M. The prevalence of the metabolic syndrome and its risk factors in a middle-aged Swedish population-mainly a function of overweight? Eur J Cardiovasc Nurs 2008; 7 : 21-6; http://dx.doi.org/10.1016/j.ejcnurse.2007.05.003

16. Hillier TA, Fagot-Campagna A, Eschwege E, et al. Weight change and changes in the metabolic syndrome as the French population moves towards overweight: the D.E.S.I.R. cohort. Int J Epidemiol 2006; 35: 190-6; http://dx.doi.org/10.1093/ije/dyi281

17. Ervin RB. Prevalence of Metabolic Syndrome among Adults 20 Years of Age and Over, by Sex, Age, Race and Ethnicity, and Body Mass Index: United States, 2003-2006. National Health Statistics Reports. Hyattsville, MD: National Center for Health Statistics 13, 2009

18. Kanjilal S, Shanker J, Rao VS, et al. Prevalence and component analysis of metabolic syndrome: An Indian atherosclerosis research study perspective. Vasc Health Risk Manag 2008; 4: 189-97; http:// dx.doi.org/10.2147/vhrm.2008.04.01.189

19. Misra A, Khurana L. Obesity and the Metabolic Syndrome in Developing Countries. J Clin Endocrinol Metab 2008; 93: S9-S30; http://dx.doi.org/10.1210/jc.2008-1595

20. Misra A, Misra R. Asian Indians and insulin resistance syndrome: Global perspective. Metab Syndr Relat Disord 2003; 1: 277-85; http://dx.doi.org/10.1089/1540419031361390

21. Grundy SM, Brewer HB, Cleeman JI, et al. National Heart and Blood Institute, American Heart Association. Definition of metabolic syndrome: report of the National Heart, Lung and Blood Institute/American Heart Association conference on scientific issues related to definition. Circulation 2004; 109: 433-8; http://dx.doi.org/10.1161/01.CIR.0000112379.88385.67

22. Guize L, Thomas F, Pannier B, et al. Metabolic syndrome: prevalence, risk factors and mortality in a French population of 62000 subjects. Bull Acad Natl Med 2006; 190: 685-97

23. Ford ES, Giles WH, Dietz WH. Prevalence of the metabolic syndrome among US adults: findings from the Third National Health and Nutrition Examination Survey. JAMA 2002; 287: 356-9; http:// dx.doi.org/10.1001/jama.287.3.356 
24. Misra A, Vikram NK. Factors, definitions, predictive value \& Asian Indian ethnicity: Complexities of the metabolic syndrome. Indian J Med Res 2008; 127: 293-6

25. Kamble P, Deshmukh PR, Garg N. Metabolic syndrome in adult population of rural Wardha, central India. Indian J Med Res 2010; 132: 701-5

26. Prabhakaran $\mathrm{D}$, Chaturvedi V, Shah $\mathrm{P}$, et al. Differences in the prevalence of metabolic syndrome in urban and rural India: a problem of urbanization. Chronic Illn 2007; 3: 8-19; http://dx.doi. org/10.1177/1742395307079197

27. Mohan V, Gokulakrishnan K, Deepa R, et al. Association of physical inactivity with components of metabolic syndrome and coronary artery disease; the Chennai Urban Population Study (CUPS no. 15). Diabetic Med 2005; 22: 1206-11; http://dx.doi.org/10.1111/j.1464-5491.2005.01616.x

28. Eapen D, Kalra GL, Merchant N, et al. Metabolic syndrome and cardiovascular disease in South Asians. Vasc Health Risk Manag 2009; 5: 731-43

29. The World Bank. Region South Asia. Available at: http://www.worldbank.org/en/region/sar (Last accessed March 2015)

30. Misra A, Misra R, Wijesuriya M, et al. The metabolic syndrome in South Asians: continuing escalation \& possible solutions. Indian J Med Res 2007; 125: 345-54

31. Yeolekar ME. Coronary artery disease in Asian Indians. J Postgrad Med 1998; 44: 26-8

32. Ramchandran A, Snehalatha C, Satyavani K, et al. Metabolic syndrome in urban Asian Indian adults - a population study using modified ATP-III criteria. Diabetes Res Clin Pract 2003; 60: 199204; http://dx.doi.org/10.1016/S0168-8227(03)00060-3

33. Smith C, Essop MF. Gender differences in metabolic risk factor prevalence in a South African student population. Cardiovasc J Africa 2009; 20: 178-82

34. Regitz-Zagroek V, Lehmkuhl E, Mahmoodzadeh S. Gender aspects of the role of the metabolic syndrome as a risk factor for cardiovascular disease. Gen Med 2007; 4: S162-77

35. Perel P, Langenberg C, Ferrie J, et al. Household wealth and the metabolic syndrome in the Whitehall II study. Diabetes Care 2006; 29: 2694-700; http://dx.doi.org/10.2337/dc06-0022

36. Dallongeville J, Cottel D, Ferrieres J, et al. Household income is associated with the risk of metabolic syndrome in a sex-specific manner. Diabetes Care 2005; 28: 409-15; http://dx.doi.org/10.2337/ diacare.28.2.409

37. Brunner EJ, Marmot MG, Nanchahal K, et al. Social inequality in coronary risk: central obesity and the metabolic syndrome. Evidence from the Whitehall II study. Diabetologia 1997; 40: 1341-9; http://dx.doi.org/10.1007/s001250050830

38. Loucks EB, Magnusson KT, Cook S, et al. Socioeconomic Position and the Metabolic Syndrome in Early, Middle, and Late Life: Evidence from NHANES 1999-2002. Ann Epidemiol 2007; 17: 782-90; http://dx.doi.org/10.1016/j.annepidem.2007.05.003

39. Park MJ, Yun KE, Lee GE, et al. A cross-sectional study of socioeconomic status and the metabolic syndrome in Korean adults. Ann Epidemiol 2007; 17: 320-6; http://dx.doi.org/10.1016/j. annepidem.2006.10.007

40. Kim MH, Kim MK, Choi BY, et al. Prevalence of metabolic syndrome and its association with cardiovascular disease in Korea. J Korean Med Sci 2004; 19: 195-201; http://dx.doi.org/10.3346/ jkms.2004.19.2.195

41. Ferguson TS, Tulloch-Reid MK, Younger NOM, et al. Prevalence of the metabolic syndrome and its components in relation to socioeconomic status among Jamaican young adults: a crosssectional study. BMC Public Health 2010; 10: 307; http://dx.doi.org/10.1186/1471-2458-10-307

42. Du S, Mroz TA, Zhai F, et al. Rapid income growth adversely affects diet quality in China - Particularly for the poor! Soc Sci Med 2004; 59: 1505-15; http://dx.doi.org/10.1016/j.socscimed.2004.01.021

43. Sharifi F, Mousavinasab SN, Saeini M, et al. Prevalence of Metabolic Syndrome in an Adult Urban Population of the West of Iran. Exp Diabetes Res 2009: 136501; http://dx.doi. org/10.1155/2009/136501 
44. Deepa M, Farooq S, Datta M, et al. Prevalence of metabolic syndrome using WHO, ATP-III and IDF definitions in Asian Indians: the Chennai Urban Rural Epidemiology Study (CURES-34). Diabetes Metab Res Rev 2007; 23: 127-34; http://dx.doi.org/10.1002/dmrr.658

45. Siedlecka J. Risk of coronary heart disease in middle-aged male bus and tram drivers compared to men in other occupations: A prospective study. Int J Epidemiol 1991; 20: 82-7; http://dx.doi. org/10.1093/ije/20.1.82

46. Kim E, Oh SW. Gender Differences in the Association of Occupation with Metabolic Syndrome in Korean Adults. Korean J Obes 2012; 21: 108-14; http://dx.doi.org/10.7570/kjo.2012.21.2.108

47. Myong JP, Kim HR, Jung-Choi K, et al. Disparities of metabolic syndrome prevalence by age, gender and occupation among Korean adult workers. Ind Health 2012; 50: 115-22; http://dx.doi. org/10.2486/indhealth.MS1328

48. Yoon H, Lee K, Kang D. Association between occupation and metabolic syndrome in Korean population: data from the fourth Korea National Health and Nutrition Examination (KNHANES), Conference proceedings, 2012

49. Saberi HR, Moravveji AR, Fakharian E, et al. Prevalence of metabolic syndrome in bus and truck drivers in Kashan, Iran. Diabetol Metab Syndr 2011; 3: 8; http://dx.doi.org/10.1186/1758-5996-3-8

50. Fan JG, Cai XB, Li L, et al. Alcohol consumption and metabolic syndrome among Shanghai adults: a randomized multistage stratified cluster sampling investigation. World J Gastroenterol 2008; 14: 2418-24; http://dx.doi.org/10.3748/wjg.14.2418

51. He K, Liu K, Daviglus ML, et al. Magnesium Intake and Incidence of Metabolic Syndrome Among Young Adults. Circulation 2006; 113: 1675-82; http://dx.doi.org/10.1161/ CIRCULATIONAHA.105.588327

52. Li ZY, Xu GB, Xia TA. Prevalence rate of metabolic syndrome and dyslipidemia in a large professional population in Beijing. Atherosclerosis 2006; 184: 188-92; http://dx.doi.org/10.1016/j. atherosclerosis.2005.03.033

53. Park HS, Lee SY, Kim SM, et al. Prevalence of the metabolic syndrome among Korean adults according to the criteria of the International Diabetes Federation. Diabetes Care 2006; 29: 933-4; http://dx.doi.org/10.2337/diacare.29.04.06.dc06-0069

54. Reddy KS, Prabhkaran D, Chaturvedi V, et al. Methods for establishing a surveillance system for cardiovascular diseases in Indian industrial populations. Bull World Health Organ 2006; 84: 461-9; http://dx.doi.org/10.2471/BLT.05.027037

55. Sanisoglu SY, Oktenli C, Hasimi A, et al. Prevalence of metabolic syndrome-related disorders in a large adult population in Turkey. BMC Public Health 2006; 6: 92; http://dx.doi.org/10.1186/14712458-6-92

56. Park HS, Oh SW, Cho SI, et al. The metabolic syndrome and associated lifestyle factors among South Korean adults. Int J Epidemiol 2004; 33: 328-36; http://dx.doi.org/10.1093/ije/dyh032

57. Al-Lawati JA, Mohammed AJ, Al-Hinai HQ, et al. Prevalence of the metabolic syndrome among Omani adults. Diabetes Care 2003; 26: 1781-5; http://dx.doi.org/10.2337/diacare.26.6.1781

58. Adams RJ, Appleton S, Wilson DH, et al. Population comparison of two clinical approaches to the metabolic syndrome: implications of the new International Diabetes Federation consensus definition. Diabetes Care 2005; 28: 2777-9; http://dx.doi.org/10.2337/diacare.28.11.2777

59. Athyros VG, Ganotakis ES, Elisaf M, et al. The prevalence of the metabolic syndrome using the National Cholesterol Educational Program and International Diabetes Federation definitions. Curr Med Res Opin 2005; 21: 1157-9; http://dx.doi.org/10.1185/030079905X53333

60. Boronat M, Chirino R, Varillas VF, et al. Prevalence of the metabolic syndrome in the island of Gran Canaria: comparison of three major diagnostic proposals. Diabet Med 2005; 22: 1751-6; http://dx.doi.org/10.1111/j.1464-5491.2005.01745.x 
61. Florez H, Silva E, Fernandez V, et al. Prevalence and risk factors associated with the metabolic syndrome and dyslipidemia in White, Black, Amerindian and Mixed Hispanics in Zulia State, Venezuela. Diabetes Res Clin Pract 2005; 69: 63-77; http://dx.doi.org/10.1016/j.diabres.2004.11.018

62. Ford ES. Prevalence of the metabolic syndrome defined by the International Diabetes Federation among adults in the U.S. Diabetes Care 2005; 28: 2745-9

63. Ishizaka $\mathrm{N}$, Ishizaka $\mathrm{Y}$, Toda $\mathrm{E}$, et al. Hypertension is the most common component of metabolic syndrome and the greatest contributor to carotid arteriosclerosis in apparently healthy Japanese individuals. Hypertens Res 2005; 28: 27-34; http://dx.doi.org/10.1291/hypres.28.27

64. Lorenzo C, Williams K, Gonzalez-Villalpando C, et al. The prevalence of the metabolic syndrome did not increase in Mexico City between 1990-1992 and 1997-1999 despite more central obesity. Diabetes Care 2005; 28: 2480-5; http://dx.doi.org/10.2337/diacare.28.10.2480

65. Thomas GN, Ho SY, Janus ED, et al. Hong Kong Cardiovascular Risk Factor Prevalence Study Steering Committee. The US National Cholesterol Education Programme Adult Treatment Panel III (NCEP ATP III) prevalence of the metabolic syndrome in a Chinese population. Diabetes Res Clin Pract 2005; 67: 251-7; http://dx.doi.org/10.1016/j.diabres.2004.07.022

66. Ford ES, Giles WH, Mokdad AH. Increasing prevalence of the metabolic syndrome among US adults. Diabetes Care 2004; 27: 2444-9; http://dx.doi.org/10.2337/diacare.27.10.2444

67. Hu FB, Meigs JB, Li TY, et al. Inflammatory markers and risk of developing type 2 diabetes in women. Diabetes 2004; 53: 693-700; http://dx.doi.org/10.2337/diabetes.53.3.693

68. Ilanne-Parikka P, Eriksson JG, Lindström J, et al. Finnish Diabetes Prevention Study Group: Prevalence of the metabolic syndrome and its components: findings from a Finnish general population sample and the Diabetes Prevention Study cohort. Diabetes Care 2004; 27: 2135-40; http://dx.doi.org/10.2337/diacare.27.9.2135

69. Jorgensen ME, Bjerregaard P, Gyntelberg F, et al. Greenland Population Study: Prevalence of the metabolic syndrome among the Inuit in Greenland. A comparison between two proposed definitions. Diabet Med 2004; 21: 1237-42; http://dx.doi.org/10.1111/j.1464-5491.2004.01294.x

70. Azizi F, Salehi P, Etemadi A, et al. Prevalence of metabolic syndrome in an urban population: Tehran Lipid and Glucose Study. Diabetes Res Clin Pract 2003; 61: 29-37; http://dx.doi.org/10.1016/ S0168-8227(03)00066-4

71. Park YW, Zhu S, Palaniappan L, et al. The metabolic syndrome: prevalence and associated risk factor findings in the US population from the Third National Health and Nutrition Examination Survey, 1988-1994. Arch Intern Med 2003; 163: 427-36; http://dx.doi.org/10.1001/archinte.163.4.427

72. Villegas R, Perry IJ, Creagh D, et al. Prevalence of the metabolic syndrome in middle-aged men and women. Diabetes Care 2003; 26: 3198-9; http://dx.doi.org/10.2337/diacare.26.11.3198-a

73. Taskar PR, O’Neil CE, Nicklas TA, et al. Dietary patterns associated with metabolic syndrome, Socio-demographic and lifestyle factors in young adults: the Bogalusa Heart Study. Public Health Nutr 2009; 12: 2493-503; http://dx.doi.org/10.1017/S1368980009991261

74. León Latre M, Andrés EM, Cordero A, et al. Relationship between metabolic syndrome and ischemic heart disease mortality in Spain. Rev Esp Cardiol 2009; 62: 1469-72; http://dx.doi. org/10.1016/s1885-5857(09)73544-3

75. Taraghi Z, Ilali E. Hypertension screening in truck drivers. HAYAT 2004; 10: 63-70

76. Carr DB, Utzschneider KM, Hull RL, et al. Intra-abdominal fat is a major determinant of the National Cholesterol Education Program Adult Treatment Panel III criteria for the metabolic syndrome. Diabetes 2004; 53: 2087-94; http://dx.doi.org/10.2337/diabetes.53.8.2087

77. Lemieux I, Pascot A, Couillard C, et al. Hypertriglyceridemic waist: a marker of the atherogenic metabolic triad (hyperinsulinemia; hyperapolipoprotein B; small, dense LDL) in men? Circulation 2000; 102: 179-84; http://dx.doi.org/10.1161/01.CIR.102.2.179

78. Ferrannini E, Haffner SM, Mitchell BD, et al. Hyperinsulinemia: the key feature of a cardiovascular and metabolic syndrome. Diabetologia 1991; 34: 416-22; http://dx.doi.org/10.1007/BF00403180 
79. Gustat J, Srinivasan SR, Elkasabany A, et al. Relation of self-rated measures of physical activity to multiple risk factors of insulin resistance syndrome in young adults: the Bogalusa Heart Study. $J$ Clin Epidemiol 2002; 55: 997-1006; http://dx.doi.org/10.1016/S0895-4356(02)00427-4

80. Apridonidze T, Essah PA, Iuorno MJ, et al. Prevalence and characteristics of the metabolic syndrome in women with polycystic ovary syndrome. J Clin Endocrinol Metab 2004; 90: 1929-35; http://dx.doi.org/10.1210/jc.2004-1045

81. Buckland G, Salas-Salvadó J, Roure E, et al. Socio-demographic risk factors associated with metabolic syndrome in a Mediterranean population. Public Health Nutr 2008; 11: 1372-8; http:// dx.doi.org/10.1017/S1368980008003492

82. Noto D, Barbagallo CM, Cefalù AB, et al. The metabolic syndrome predicts cardiovascular events in subjects with normal fasting glucose: results of a 15 years follow-up in a Mediterranean population. Atherosclerosis 2008; 197: 147-53; http://dx.doi.org/10.1016/j.atherosclerosis.2007.03.005

83. Krishnaswamy K. Evolutionary Aspects Of Diets In The Context Of Current Chronic Diseases. NFI Bulletin 2012; 33

84. Serra-Majem Ll, Ngo J, Ribas L, et al. Olive oil and the Mediterranean diet: beyond the rethoric. Eur J Clin Nutr 2003; 57: 2S-7S; http://dx.doi.org/10.1038/sj.ejcn.1601801

85. Landaeta-Díaz L, Fernández JM, Da Silva-Grigoletto M, et al. Mediterranean diet, moderate-tohigh intensity training, and health-related quality of life in adults with metabolic syndrome. Eur J Prev Cardiol. 2012; 20: 555-64; http://dx.doi.org/10.1177/2047487312445000

86. Jones JL, Fernandez ML, McIntosh MS, et al. A Mediterranean-style low-glycemic-load diet improves variables of metabolic syndrome in women, and addition of a phytochemical-rich medical food enhances benefits on lipoprotein metabolism. J Clin Lipidol 2011; 5: 188-96; http:// dx.doi.org/10.1016/j.jacl.2011.03.002

87. Rumawas ME, Meigs JB, Dwyer JT, et al. Mediterranean-style dietary pattern, reduced risk of metabolic syndrome traits, and incidence in the Framingham Offspring Cohort1-3. Am J Clin Nutr 2009; 90: 1608-14; http://dx.doi.org/10.3945/ajcn.2009.27908

88. Nourian M. The Effect of Nutrition Education Intervention on some related risk factors among subjects with Metabolic Syndrome, Department of Nutrition and Dietetics, Faculty of Medicine and Health Sciences, University Putra Malaysia, 2008

89. Michalsen A, Lehmann N, Pithan C, et al. Mediterranean diet has no effect on markers of inflammation and metabolic risk factors in patients with coronary artery disease. Eur J Clin Nutr 2006; 60: 478-85; http://dx.doi.org/10.1038/sj.ejcn.1602340

90. Esposito K, Marfella R, Ciotola M, et al. Effect of a Mediterranean style diet on endothelial dysfunction and markers of vascular inflammation in the metabolic syndrome: a randomized trial. JAMA 2004; 292: 1440-6; http://dx.doi.org/10.1001/jama.292.12.1440

91. Appleby P, Davey G, Key T. Hypertension and blood pressure among meat eaters, fish eaters, vegetarians and vegans in EPIC-Oxford. Public Health Nutr 2002; 5: 645-54; http://dx.doi. org/10.1079/PHN2002332

92. Banos G, Pérez-Torres I, El Hafidi M. Medicinal agents in the metabolic syndrome. Cardiovasc Hematol Agents Med Chem 2008; 6: 237-52; http://dx.doi.org/10.2174/187152508785909465

93. Sofi F, Cesari F, Abbate R, et al. Adherence to Mediterranean diet and health status: meta-analysis. BMJ 2008; 337: a1344

94. Landaeta-Díaz L, Fernández JM, Da Silva-Grigoletto M, et al. Mediterranean diet, moderate-tohigh intensity training and health-related quality of life in adults with metabolic syndrome. Eur $J$ Prev Cardiol 2013; 20: 555-64; http://dx.doi.org/10.1177/2047487312445000

95. Pérez-López FR, Chedraui P, Haya J, et al. Effects of the Mediterranean diet on longevity and age-related morbid conditions. Maturitas 2009; 64: 67-79; http://dx.doi.org/10.1016/j. maturitas.2009.07.013 
96. Alvarez Leon EE, Henriquez P, Serra-Majem L. Mediterranean diet and metabolic syndrome: a cross-sectional study in the Canary Islands. Public Health Nutr 2006; 9: 1089-98; http://dx.doi. org/10.1017/S1368980007668487

97. Yoo S, Nicklas T, Baranowski T, et al. Comparison of dietary intakes associated with metabolic syndrome risk factors in young adults: the Bogalusa Heart Study. Am J Clin Nutr 2004; 80: 841-8

98. Kastorini CM, Milionis HJ, Esposito K, et al. The Effect of Mediterranean Diet on Metabolic Syndrome and its Components: A Meta-Analysis of 50 Studies and 534,906 Individuals. J Am Coll Cardiol 2011; 57: 1299-313; http://dx.doi.org/10.1016/j.jacc.2010.09.073

99. Brown AA, Hu FB. Dietary modulation of endothelial function: implications for cardiovascular disease. Am J Clin Nutr 2001; 73: 673-86

100. Shacky VC. N-3 fatty acids and prevention of coronary atherosclerosis. Am J Clin Nutr 2000; 71: 224S-7S

101. Vessby B. Dietary fat and insulin action in humans. Br J Nutr 2000; 83: 591-6; http://dx.doi. org/10.1017/S000711450000101X

102. Connor WE. Importance of $\mathrm{n}-3$ fatty acids in health and disease. Am J Clin Nutr 2000; 71: $171 \mathrm{~S}-175 \mathrm{~S}$

103. Hajjar IM, Grim CE, Kotchen TA. Dietary calcium lowers the age related rise in blood pressure in the United States: the NHANES III survey. J Clin Hypertens 2003 ;5: 122-6; http://dx.doi. org/10.1111/j.1524-6175.2003.00963.x

104. Jorde R, Bonna KH. Calcium from dairy products, vitamin D intake, and blood pressure: the Tromso Study. Am J Clin Nutr 2000; 71: 1530-5

105. Ness AR, Smith GD, Hart C. Milk, coronary heart disease and mortality. J Epidemiol Community Health 2001; 55: 379-82; http://dx.doi.org/10.1136/jech.55.6.379

106. Azadbakht L, Mirmiran P, Esmaillzadeh A, et al. Dairy consumption is inversely associated with the prevalence of the metabolic syndrome in Tehranian adults. Am J Clin Nutr 2005; 82: 523-30

107. Zemel MB, Shi H, Greer B, et al. Regulation of adiposity by dietary calcium. FASEB J 2000; 14 : 1132-8

108. Fleming KH, Heimbach JT. Consumption of calcium in the US: food sources and intake levels. J Nutr 1994; 124: 1426S -1430S

109. Bursey RG, Sharkey T, Miller GD. High calcium intake lowers weight in lean and fatty zucker rats. FASEB J 1989; 3137: A265

110. McCarron DA, Morris CD, Henry HJ, et al. Blood pressure and nutrient intake in the United States. Science 1984; 224: 1392-8; http://dx.doi.org/10.1126/science.6729459

111. Lin YC, Lyle RM, McCabe LD, et al. Dairy calcium is related to changes in body composition during a two year exercise intervention in young women. J Am Coll Nutr 2000; 19: 754-60; http:// dx.doi.org/10.1080/07315724.2000.10718075

112. Trichopoulou A, Costacou T, Bamia C, et al. Adherence to a Mediterranean diet and survival in a Greek population. N Engl J Med 2003; 348: 2599-608; http://dx.doi.org/10.1056/NEJMoa025039

113. Mennen L, Lafay L, Feskens EJ, et al. Possible protective effect of bread and dairy products on the risk of the metabolic syndrome. Nutr Res 2000; 20: 335-47; http://dx.doi.org/10.1016/S02715317(00)00127-5

114. Pereira MA, Jacobs DR Jr, Van Horn L, et al. Dairy consumption, obesity, and the insulin resistance syndrome in young adults: the CARDIA Study. JAMA 2002; 287: 2081-9; http://dx.doi.org/10.1001/ jama.287.16.2081

115. Pettman TL, Buckley JD, Misan GMH, et al. Health benefits of a 4-month group-based diet and lifestyle modification program for individuals with metabolic syndrome. Obes Res Clin Prac 2009; 3: 221-35; http://dx.doi.org/10.1016/j.orcp.2009.06.002 
116. Jenkins DJ, Kendall CW, Marchie A, et al. Direct comparison of dietary portfolio vs statin on C-reactive protein. Eur J Clin Nutr 2005; 59: 851-60; http://dx.doi.org/10.1038/sj.ejcn.1602152

117. Song Y, Ridker PM, Manson JE, et al. Magnesium intake, C-reactive protein, and the prevalence of metabolic syndrome in middle-aged and older U.S. women. Diabetes Care 2005; 28: 1438-44; http://dx.doi.org/10.2337/diacare.28.6.1438

118. Guerrero-Romero F, Rodriguez-Moran M. Low serum magnesium levels and metabolic syndrome. Acta Diabetol 2002; 39: 209-13; http://dx.doi.org/10.1007/s005920200036

119. Stefanick ML, Mackey S, Sheehan M, et al. Effects of diet and exercise in men and postmenopausal women with low levels of HDL cholesterol and high levels of LDL cholesterol. N Engl J Med 1998; 339: 12-20; http://dx.doi.org/10.1056/NEJM199807023390103

120. Lopez-Ridaura R, Willett WC, Rimm EB, et al. Magnesium intake and risk of type 2 diabetes in men and women. Diabetes Care 2004; 27: 134-40; http://dx.doi.org/10.2337/diacare.27.1.134

121. Song Y, Manson JE, Buring JE, et al. Dietary magnesium intake in relation to plasma insulin levels and risk of type 2 diabetes in women. Diabetes Care 2004; 27: 59-65; http://dx.doi.org/10.2337/ diacare.27.1.59

122. Kao WH, Folsom AR, Nieto FJ, et al. Serum and dietary magnesium and the risk for type 2 diabetes mellitus: the Atherosclerosis Risk in Communities Study. Arch Intern Med 1999; 159 : 2151-9; http://dx.doi.org/10.1001/archinte.159.18.2151

123. Barbagallo M, Dominguez LJ, Galioto A, et al. Role of magnesium in insulin action, diabetes and cardio-metabolic syndrome X. Mol Aspects Med 2003; 24: 39-52; http://dx.doi.org/10.1016/S00982997(02)00090-0

124. Paolisso G, Barbagallo M. Hypertension, diabetes mellitus, and insulin resistance: the role of intracellular magnesium. Am J Hypertens 1997; 10: 346-55; http://dx.doi.org/10.1016/S08957061(96)00342-1

125. Teixeira Rde C, Molina Mdel C, Zandonade E, et al. Cardiovascular risk in vegetarians and omnivores: a comparative study. Arq Bras Cardiol 2007; 89: 237-44

126. Rizzo NS, Sabaté J, Jaceldo-Siegl K, et al. Vegetarian Dietary Patterns Are Associated With a Lower Risk of Metabolic Syndrome: The Adventist Health Study 2. Diabetes Care 2011; 34: 1225-7; http:// dx.doi.org/10.2337/dc10-1221

127. Toohey ML, Harris MA, DeWitt W, et al. Cardiovascular disease risk factors are lower in AfricanAmerican vegans compared to lacto-ovo-vegetarians. J Am Coll Nutr 1998; 17: 425-34; http:// dx.doi.org/10.1080/07315724.1998.10718789

128. De Biase SG, Fernandes SF, Gianini RJ, et al. Vegetarian diet and cholesterol and triglycerides levels. Arq Bras Cardiol 2007; 88: 35-9; http://dx.doi.org/10.1590/S0066-782X2007000100006

129. Daniel CR, Prabhakaran D, Kapur K, et al. A cross-sectional investigation of regional patterns of diet and cardio-metabolic risk in India. Nutr J 2011; 28: 12; http://dx.doi.org/10.1186/1475-2891$10-12$

130. Rastogi T, Reddy KS, Vaz M, et al. Diet and risk of ischemic heart disease in India. Am J Clin Nutr 2004; 79: 582-92

131. Kinra S, Bowen LJ, Lyngdoh T, et al. Sociodemographic patterning of non-communicable disease risk factors in rural India: a cross sectional study. BMJ 2010; 341: c4974; http://dx.doi.org/10.1136/ bmj.c4974

132. Psaltopoulou T, Naska A, Orfanos P, et al. Olive oil, the Mediterranean diet, and arterial blood pressure: the Greek European Prospective Investigation into Cancer and Nutrition (EPIC) study. Am J Clin Nutr 2004; 80: 1012-8

133. Schroder H, Ferra'ndez O, Jime'nez Conde J, et al. Cardiovascular risk profile and type of alcohol beverage consumption: a population-based study. Ann Nutr Metab 2005; 49: 100-6; http://dx.doi. org/10.1159/000084889 
134. Vernay M, Balkau B, Moreau JG, et al. Desir study group. Alcohol consumption and insulin resistance syndrome parameters: associations and evolutions in a longitudinal analysis of the French DESIR cohort. Ann Epidemiol 2004; 14: 209-14; http://dx.doi.org/10.1016/S10472797(03)00131-5

135. Yoon YS, Oh SW, Baik HW, et al. Alcohol consumption and the metabolic syndrome in Korean adults: the 1998 Korean National Health and Nutrition Examination Survey. Am J Clin Nutr 2004; 80: $217-24$

136. Alkerwi A, Boutsen M, Vaillant M, et al. Alcohol consumption and the prevalence of metabolic syndrome: a meta-analysis of observational studies. Atherosclerosis 2009; 204: 624-35; http:// dx.doi.org/10.1016/j.atherosclerosis.2008.10.036

137. Rosell M, De Faire U, Hellénius ML. Low prevalence of the metabolic syndrome in wine drinkers-is it the alcohol beverage or the lifestyle? Eur J Clin Nutr 2003; 57: 227-34; http://dx.doi.org/10.1038/ sj.ejcn.1601548

138. Baik I, Shin C. Prospective study of alcohol consumption and metabolic syndrome. Am J Clin Nutr 2008; 87: 1455-63

139. Freiberg MS, Cabral HJ, Heeren TC, et al. Alcohol consumption and the prevalence of the metabolic syndrome in the US: a cross sectional analysis of data from the Third National Health and Nutrition Examination Survey. Diabetes Care 2004; 27: 2954-9; http://dx.doi.org/10.2337/ diacare.27.12.2954

140. Djousse L, Ellison RC, Beiser A, et al. Alcohol consumption and risk of ischemic stroke: the Framingham Study. Stroke 2002; 33: 907-12; http://dx.doi.org/10.1161/hs0402.105245

141. Ronnemaa T, Ronnemaa EM, Puukka P, et al. Smoking is independently associated with high plasma insulin levels in nondiabetic men. Diabetes Care 1996; 19: 1229-32; http://dx.doi. org/10.2337/diacare.19.11.1229

142. Facchini FS, Hollenbeck CB, Jeppesen J, et al. Insulin resistance and cigarette smoking. Lancet 1992; 339: 1128-30; http://dx.doi.org/10.1016/0140-6736(92)90730-Q

143. World Health Organization Western Pacific Region. International Association for the Study of Obesity, International Obesity Task Force: The Asia-Pacific Perspective: Redefining Obesity and its Treatment. Sydney: Health Communications Australia, 2000

144. Oh SW, Yoon YS, Lee ES, et al. Association between Cigarette Smoking and Metabolic Syndrome: The Korea National Health and Nutrition Examination Survey. Diabetes Care 2005; 28: 2064-6; http://dx.doi.org/10.2337/diacare.28.8.2064

145. Dyer AR, Stamler J, Shekelle RB, et al. Pulse pressure II. Factors associated with follow-up values in three Chicago epidemiologic studies. J Chronic Dis 1982; 35: 275-82; http://dx.doi. org/10.1016/0021-9681(82)90083-2

146. Elliott JM, Simpson FO. Cigarettes and accelerated hypertension. N Z Med J 1980; 91: 447-9

147. Rimm EB, Chan J, Stampfer MJ, et al. Prospective study of cigarette smoking, alcohol use, and the risk of diabetes in men. BMJ 1995; 310: 555-9; http://dx.doi.org/10.1136/bmj.310.6979.555

148. Feskens EJ, Kromhout D. Cardiovascular risk factors and the 25 -year incidence of diabetes mellitus in middle-aged men: the Zutphen Study. Am J Epidemiol 1989; 130: 1101-8

149. Corwin EJ, McCoy CS, Whetzel CA, et al. Risk indicators of metabolic syndrome in young adults: A preliminary investigation on the influence of tobacco smoke exposure and gender. Heart Lung 2006; 35: 119-29; http://dx.doi.org/10.1016/j.hrtlng.2005.09.003

150. Hopps E, Noto D, Caimi G, et al. A novel component of the metabolic syndrome: The oxidative stress. Nutr Metab Cardiovasc Dis 2010; 20: 72-7; http://dx.doi.org/10.1016/j.numecd.2009.06.002

151. Demircan N, Gurel A, Armuctu F, et al. The evaluation of serum cystatin C, malonildialdehyde and total antioxidant status in patients with metabolic syndrome. Med Sci Monit 2008; 14: e97-e101 
152. Ford ES, Mokdad AH, Giles WH, et al. The metabolic syndrome and antioxidant concentrations. Diabetes 2003; 52: e2346-e2352; http://dx.doi.org/10.2337/diabetes.52.9.2346

153. Demirbag R, Yilmaz R, Gur M, et al. DNA damage in metabolic syndrome and its association with antioxidative and oxidative measurements. Int J Clin Pract 2006; 60: e1187-e1193; http://dx.doi. $\operatorname{org} / 10.1111 / \mathrm{j} .1742-1241.2006 .01042 . \mathrm{x}$

154. Burcelin R. Regulation of metabolism: a cross talk between gut microbiota and its human host. Physiology 2012; 27: 300-7; http://dx.doi.org/10.1152/physiol.00023.2012

155. Ding S, Chi MM, Scull BP, et al. High-fat diet: bacteria interactions promote intestinal inflammation which precedes and correlates with obesity and insulin resistance in mouse. PLoS One 2010; 16; 5: e12191

156. Amar J, Serino M, Lange C,et al.; D.E.S.I.R. Study Group. Involvement of tissue bacteria in the onset of diabetes in humans: evidence for a concept. Diabetologia 2011; 54: 3055-61; http://dx.doi. org/10.1007/s00125-011-2329-8

157. Ramadhani MK, Grobbee DE, Bots ML, et al. Lower birth weight predicts metabolic syndrome in young adults: The Atherosclerosis Risk in Young Adults (ARYA)-study. Atherosclerosis 2006; 184: 21-7; http://dx.doi.org/10.1016/j.atherosclerosis.2005.03.022

158. Cook S, Weitzman M, Auinger P, et al. Prevalence of a metabolic syndrome phenotype in adolescents: findings from the third National Health and Nutrition Examination Survey, 19881994. Arch Pediatr Adolesc Med 2003; 157: 821-7; http://dx.doi.org/10.1001/archpedi.157.8.821

159. Arslanian S, Suprasongsin C. Insulin sensitivity, lipids, and body composition in childhood: is “syndrome X" present? J Clin Endocrinol Metab 1996; 81: 1058-62; http://dx.doi.org/10.1210/ jcem.81.3.8772576

160. Srinivasan SR, Myers L, Berenson GS. Predictability of childhood adiposity and insulin for developing insulin resistance syndrome (syndrome $\mathrm{X}$ ) in young adulthood: the Bogalusa Heart Study. Diabetes 2002; 51: 204-9; http://dx.doi.org/10.2337/diabetes.51.1.204

161. Katzmarzyk PT, Perusse L, Malina RM, et al. Stability of indicators of the metabolic syndrome from childhood and adolescence to young adulthood: the Quebec Family Study. J Clin Epidemiol 2001; 54: 190-5; http://dx.doi.org/10.1016/S0895-4356(00)00315-2

162. Steinberger J, Moran A, Hong CP, et al. Adiposity in childhood predicts obesity and insulin resistance in young adulthood. J Pediatr 2001; 138: 469-73; http://dx.doi.org/10.1067/mpd.2001.112658

163. Srinivasan SR, Bao W, Wattigney WA, et al. Adolescent overweight is associated with adult overweight and related multiple cardiovascular risk factors: the Bogalusa Heart Study. Metabolism 1996; 45: 235-40; http://dx.doi.org/10.1016/S0026-0495(96)90060-8

164. Raitakari OT, Porkka KV, Rasanen L, et al. Clustering and six year cluster-tracking of serum total cholesterol, HDL-cholesterol and diastolic blood pressure in children and young adults: the Cardiovascular Risk in Young Finns Study. J Clin Epidemiol 1994; 47: 1085-93; http://dx.doi. org/10.1016/0895-4356(94)90094-9

165. Ferreira I, Twisk JWR, Mechelen W, et al. Development of Fatness, Fitness, and Lifestyle from Adolescence to the Age of 36 Years. Determinants of the Metabolic Syndrome in Young Adults:The Amsterdam Growth and Health Longitudinal Study. Arch Intern Med 2005; 165: 42-8; http:// dx.doi.org/10.1001/archinte.165.1.42

166. Barker, DJP. Mothers, Babies and Health in Later Life. 2d ed. Edinburgh, UK: Churchill Livingston, 1998

167. Huffman MD, Prabhakaran D, Osmond C, et al. New Delhi Birth Cohort. New Delhi Birth Cohort. Incidence of cardiovascular risk factors in an Indian urban cohort results from the New Delhi birth cohort. J Am Coll Cardiol 2011; 57: 1765-74; http://dx.doi.org/10.1016/j.jacc.2010.09.083

168. Hanefeld M, Koehler C, Gallo S, et al. Impact of the individual components of the metabolic syndrome and their different combinations on the prevalence of atherosclerotic vascular disease 
in type 2 diabetes: the Diabetes in Germany (DIG) study. Cardiovasc Diabetol 2007; 6: 13; http:// dx.doi.org/10.1186/1475-2840-6-13

169. Nugent PA. The metabolic syndrome. Nutr Bull 2004; 29: 36-43; http://dx.doi.org/10.1111/j.14673010.2004.00403.x

170. Carmena R. Dietary therapy of the metabolic syndrome. International Congress Series 2003; 1253 : 237-41; http://dx.doi.org/10.1016/S0531-5131(02)01279-7 